\title{
ASSOCIATIONS OF BENTHIC MACROINVERTEBRATE ASSEMBLAGES WITH ENVIRONMENTAL VARIABLES IN THE UPPER CLEAR CREEK WATERSHED, CALIFORNIA
}

\author{
Larry R. Brown ${ }^{1,2}$, Jason T. May ${ }^{1}$, and Marissa Wulff ${ }^{1}$
}

\begin{abstract}
Benthic macroinvertebrates are integral components of stream ecosystems and are often used to assess the ecological integrity of streams. We sampled streams in the upper Clear Creek drainage in the Klamath-Siskiyou Ecoregion of northwestern California in fall 2004 (17 sites) and 2005 (original 17 plus 4 new sites) with the objectives of documenting the benthic macroinvertebrate assemblages supported by the streams in the area, determining how those assemblages respond to environmental variables, assessing the biological condition of the streams using a benthic index of biotic integrity (IBI), and understanding the assemblages in the context of biodiversity of the ecoregion. We collected both reach-wide (RW) and targeted-riffle (TR) macroinvertebrate samples at each site. The macroinvertebrate assemblages were diverse, with over 150 genera collected for each sampling protocol. The macroinvertebrate assemblages appeared to be most responsive to a general habitat gradient based on stream size, gradient, flow, and dominance of riffles. A second important habitat gradient was based on elevation and dominance of riffles. A gradient in water quality based on concentrations of dissolved ions and metals was also important. Models based on these 3 gradients had Spearman's rank correlations with macroinvertebrate taxonomic composition of 0.60 and 0.50 for the TR and RW samples, respectively. The majority $(>50 \%)$ of the sites were in good or very good biological condition based on IBI scores. The diversity of macroinvertebrate assemblages is associated with the diversity of habitats available in the Klamath-Siskiyou Ecoregion. Maintaining the aquatic habitats in good condition is important in itself but is also vital to maintaining biodiversity in this diverse and unique ecoregion.
\end{abstract}

RESUMEN.-Los macroinvertebrados bentónicos son componentes integrales de los ecosistemas fluviales y por lo general se les utiliza para evaluar la integridad ecológica de los arroyos. Tomamos muestras de arroyos en la parte alta del río Clear Creek en la Ecoregión de Klamath-Siskiyou en el noroeste de California en otoño de 2004 (17 sitios) y 2005 (los 17 sitios originales más 4 sitios nuevos) con los objetivos de documentar los ensambles de invertebrados bentónicos que habitan en los arroyos del área, determinar la manera en que estos ensambles responden a las variables ambientales, evaluar la condición biológica de los arroyos mediante el uso del Índice Bentónico de Integridad Biótica (IBI), y entender los ensambles en el contexto de la biodiversidad de la ecoregión. Recolectamos muestras de macroinvertebrados a lo ancho del arroyo $(\mathrm{RW})$ y en puntos rápidos (TR) en cada sitio. Los ensambles de macroinvertebrados fueron diversos con más de 150 géneros colectados en cada protocolo de muestra. Los ensambles de macroinvertebrados parecen responder más al gradiente general del hábitat según el tamaño del arroyo, el gradiente, el caudal y la dominancia de rápidos. Un segundo gradiente importante de hábitat se basó en la elevación y la dominancia de rápidos. Un gradiente en la calidad del agua basado en las concentraciones de iones y metales disueltos también fue importante. Los modelos basados en estos tres gradientes tuvieron correlaciones de rangos de Spearman con la composición taxonómica de macroinvertebrados de 0.60 y 0.50 para las muestras de TR y RW, respectivamente. La mayoría (>50\%) de los sitios tuvieron buenas o muy buenas condiciones biológicas basadas en los valores del IBI. La diversidad de ensambles de macroinvertebrados está relacionada con la diversidad de hábitats disponibles en la Ecoregión de Klamath-Siskiyou. El mantener los hábitats acuáticos en buenas condiciones es importante en sí mismo, pero también es vital para mantener la biodiversidad en esta ecoregión diversa y única.

Because of the importance of benthic macroinvertebrates in stream ecosystems, understanding the associations of macroinvertebrates with the physical and chemical environment has been a continuing focus of stream ecology (Hynes 1970, Vannote et al. 1980, Allan 2004). Benthic macroinvertebrates are components of complex aquatic food webs (Feminella et al. 1989, Wooton et al. 1996, Power et al. 2008), and terrestrial adult phases, characteristic of many species, can act as a food subsidy for riparian invertebrate and vertebrate predators, just as riparian plants and animals provide important food and energy subsidies to stream ecosystems (Vannote et al. 1980, Nakano et al. 1999, Nakano and Murakami 2001).

In addition to their importance in ecological processes of aquatic and riparian systems,

${ }^{1}$ U.S. Geological Survey, Placer Hall, 6000 J Street, Sacramento, CA 95819.

2E-mail: lrbrown@usgs.gov 
benthic macroinvertebrates have long been recognized as important indicators of stream "health" or biological condition (Gaufin 1973, Hilsenhoff 1988, Reynoldson and MetcalfeSmith 1992). Most recently, the sensitivity of aquatic macroinvertebrates to environmental change has led to the development of various methods for characterizing biological condition of streams based on benthic macroinvertebrates, including multiple metric indices, such as various forms of the Index of Biotic Integrity (IBI) (Kerans and Karr 1994, Karr and Chu 1999, Ode et al. 2005). Such indices have become important in the monitoring of biological conditions in streams and in the development of biological objectives and criteria.

Resource managers have the responsibility of protecting and managing resources on public lands. This responsibility involves not only identifying and protecting the species within those lands but also identifying and understanding the habitats and ecological processes necessary for maintaining populations of those species in good condition. Whiskeytown National Recreation Area (WNRA) is located within the Klamath-Siskiyou Ecoregion, a globally significant area for biodiversity of terrestrial plant and animal communities (DellaSala et al. 1999). The region has a moderately rich herpetofauna of 38 species, and that richness is most likely due to overlap between northern and southern taxa and the complex and patchy nature of habitats that can support a wide range of species (Bury and Pearl 1999). Brown and May (2007) analyzed assemblage data on fishes and amphibians from the upper Clear Creek drainage, which includes WNRA, and noted that the native aquatic vertebrate assemblages were largely intact, in contrast to the situation in many other areas of California (Jennings and Hayes 1994, Knapp and Matthews 2000, Marchetti et al. 2001, Matthews et al. 2001, Moyle 2002, Brown and Moyle 2005, Knapp 2005, Marchetti et al. 2006, Welsh et al. 2006). The assemblages were unique combinations of native fishes and amphibians from the Central Valley and coastal areas of California. Unfortunately, limited published information exists on the benthic macroinvertebrate communities that form the base of the food web for stream fish and amphibians for the Klamath-Siskiyou Ecoregion in general, and none exists for the WNRA in particular.
In this paper, we present results of a study documenting the assemblages of benthic macroinvertebrates in the streams of the upper Clear Creek watershed, which is partially contained within WNRA, located in northern California. The study was part of an effort by the National Park Service to document aquatic resources associated with WNRA and understand the environmental factors affecting those resources. The primary objectives of the study were to document the benthic macroinvertebrate assemblages supported by streams in the area, determine how those assemblages respond to environmental variables, assess the utility of 2 different sampling strategies for assessing stream condition using an IBI (Rehn et al. 2005), and understand benthic macroinvertebrate assemblages in the context of biodiversity within the Klamath-Siskiyou Ecoregion. This information is critical to ensuring that local resource managers can make informed decisions regarding protection and enhancement of aquatic resources in this ecologically significant region.

\section{Methods \\ Study Area}

The study area is located in northwestern California in the upper Clear Creek watershed, mainly within WNRA (Fig. 1; described in detail in Brown and May 2007). In brief, the study area includes a variety of private and public lands. Whiskeytown National Recreation Area, where the majority of sample sites were located, is at the convergence of 3 physiographic provinces: the Cascade Range, the Coast Range, and the Sacramento Valley. The study area has a Mediterranean climate with hot $\left(>38{ }^{\circ} \mathrm{C}\right)$, dry summers and cool $\left(<0{ }^{\circ} \mathrm{C}\right)$ winters with moderate rainfall. Mean annual rainfall in the area is approximately $1500 \mathrm{~mm}$. The study area lies within the KlamathSiskiyou Ecoregion, an area of significant biodiversity, especially for terrestrial plants (DellaSala et al. 1999). The complex plant communities reflect the broad elevational range, rugged topography, diverse soil types, and history of natural and human disturbance.

The northern and southern portions of the study area are geologically distinct (Thornberry-Ehrlich 2007). South of Whiskeytown Lake, the geology is dominated by the granitic Shasta Bally basolith. North of the reservoir 


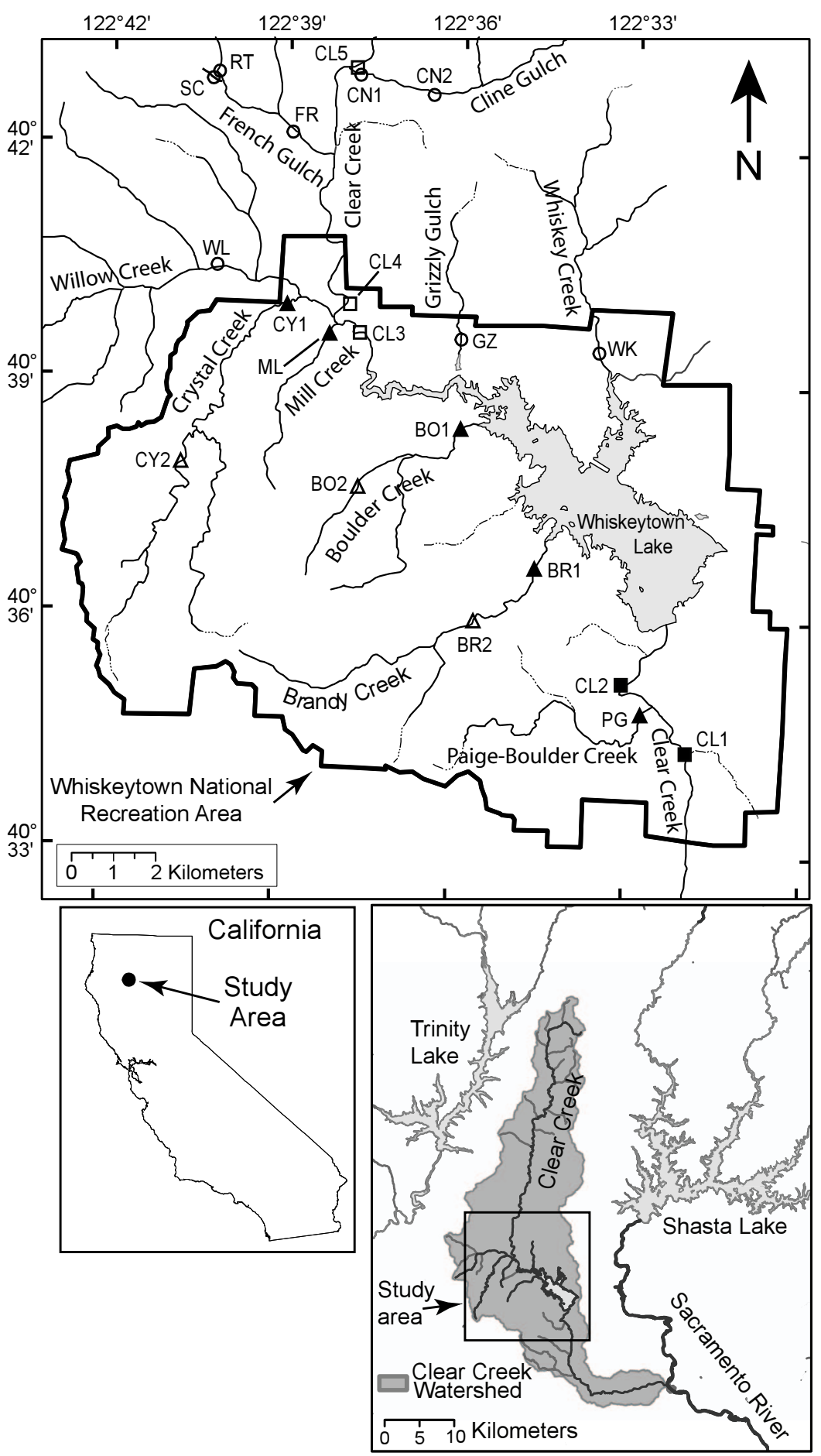

Fig. 1. Location of study sites within the upper Clear Creek watershed, California. Sites CL3, CN2, RT, and SC were sampled in only fall 2005. The other sites were sampled in fall 2004 and 2005. Symbols indicate the following groups: $\triangle$, southern streams, upper; $\boldsymbol{\Lambda}$, southern streams, lower; $\square$, Clear Creek, upper; $\mathbf{\square}$, Clear Creek, lower; $O$, northern streams. 
and in the Willow Creek drainage, the geology is dominated by an older assemblage of quartzmica schists, felsic and mafic volcanic rocks, and conglomeratic and shaly sedimentary rocks that range in age from the Precambrian to the Mississippian (Thornberry-Ehrlich 2007). The geological formations in the northern area include large deposits of precious minerals, such as gold, copper, zinc, pyrite, and silver.

There is a long history of human disturbance in the Clear Creek watershed (Thornberry-Ehrlich 2007), particularly related to mining, timber harvest, and water management. Mining in the area has been active intermittently since 1848 , including extraction of copper, zinc, pyrite, gold, and silver. Mercury was commonly used in gold processing during the early years. Mining activities left numerous dredge tailing piles, pits, tunnels, roads, and acid mine drainage, resulting in presently elevated levels of metals, including arsenic, chromium, copper, lead, mercury, and zinc, in sediments of some streams (Moore and Hughes 2003). Willow Creek is on the California 303d list of impaired waters for acid mine drainage, copper, and zinc, while Whiskeytown Lake is on the list for mercury in fish tissue (California State Water Resources Control Board 2010). Timber harvests in the watershed have left approximately $500 \mathrm{~km}$ of poorly constructed roads, making sedimentation from surface erosion and landslides a concern in the Clear Creek watershed.

Whiskeytown Lake is part of the federal Central Valley Project and stores water diverted from the Trinity River to the east. Water from Whiskeytown Lake is then diverted to a powerplant outside the Clear Creek watershed or released into lower Clear Creek, which flows into the Sacramento River, to support various human uses. Operation of the project began in 1963. The dam forming Whiskeytown Lake is the dividing line between the upper and lower drainage because of the effects of dam operations on the flow regime. Upstream of the dam, the flow regime is typical of California's Mediterranean climate, with high winter (rainfall) and spring (snowmelt) flows and low summer flows. Below the dam, winter and spring flows (December-June) are diminished due to reservoir storage, and summer and fall flows (July-November) are elevated due to release of stored water for downstream uses (USGS 2012). This pattern is typical of water supply reservoirs in the Sacramento River basin (Brown and Bauer 2010).

\section{Data Collection}

We sampled 17 sites in the fall of 2004 and 2005, plus an additional 4 new sites in the fall of 2005 (Fig. 1). Sites sampled only in 2005 were CN2, RT, SC, and CL3 (Fig. 1). Sites were selected to represent all major habitats within perennial streams in the area. Brandy, Boulder, Crystal, Mill, and Paige-Boulder Creeks represented the southern granitic geology. Brandy, Boulder, and Crystal Creeks had both high- and low-elevation sites. The lower Clear Creek downstream of the reservoir are technically in the lower basin but were included to understand the effects of the altered flow regime on Clear Creek. The remaining streams were representative of perennial streams in the WNRA region with northern geology. Reach lengths established for sampling varied from 100 to $400 \mathrm{~m}$ (Table 1). Sites were sampled once per year in September.

The 2 sampling methods we compared were a targeted-riffle (TR) and a reach-wide (RW) method. Both methods were used at each site in both years. The TR method targets riffles, a species-rich microhabitat, and the RW method samples microhabitats in proportion to their natural abundance. We collected TR samples using methods similar to those of the California State Bioassessment Procedure (CSBP, Harrington 1999). The standard CSBP includes collection of 3 replicate kicknet samples (D-frame net with 500-micron mesh and width of $0.25 \mathrm{~m}$ ) from each of 3 separate riffles. An area of about $0.1 \mathrm{~m}^{2}\left(1 \mathrm{ft}^{2}\right)$ in front of the net was disturbed for each kick sample (9 total kick samples $\left.=0.9 \mathrm{~m}^{2}\right)$. All individual kick samples were combined into a single composite sample. We collected RW quantitative multihabitat samples using methods similar to the EPA's Environmental Monitoring and Assessment Program (EMAP) (Peck et al. 2006). The sample was a composite of 11 kick samples $\left(11\right.$ total kick samples $\left.=1.1 \mathrm{~m}^{2}\right)$ with one sample taken at each of 11 equally spaced transects along the length of the stream reach at $0.25,0.50$, or 0.75 of the stream width. The same type of net was used as for the TR sample. Both TR and RW samples were sieved $(0.5 \mathrm{~mm})$, then preserved with $95 \%$ ethanol. The RW and TR samples were collected simultaneously by the same crew as the crew 
TABLE 1. Sample reach lengths, elevations, and means (SD in parentheses) for selected habitat characteristics of groups of sites sampled in the upper Clear Creek watershed, California, in fall 2004 and 2005. Range of the coefficient of variation $(\%)$ is given for selected variables. See Fig. 1 for sites included in each group.

\begin{tabular}{|c|c|c|c|c|c|}
\hline Variable & $\begin{array}{l}\text { Southern } \\
\text { Streams } \\
\text { (upper) }\end{array}$ & $\begin{array}{c}\text { Southern } \\
\text { streams } \\
\text { (lower) }\end{array}$ & $\begin{array}{c}\text { Clear } \\
\text { Creek } \\
\text { (lower) }\end{array}$ & $\begin{array}{c}\text { Clear } \\
\text { Creek } \\
\text { (upper) }\end{array}$ & $\begin{array}{l}\text { Northern } \\
\text { streams }\end{array}$ \\
\hline Reach length (m) & 100 & 150 & 400 & 400 & $150^{\mathrm{a}}$ \\
\hline Number of samples ${ }^{b}$ & 6 & 10 & 4 & 5 & 13 \\
\hline Elevation $(\mathrm{m})$ & $1915(438)$ & $1238(161)$ & $917(28)$ & $1298(87)$ & $1518(229)$ \\
\hline Gradient (\%) & $10.1(0.8)$ & $3.4(0.8)$ & $0.5(0.2)$ & $0.5(0.2)$ & $3.5(2.7)$ \\
\hline Discharge $\left(\mathrm{m}^{3} \cdot \mathrm{s}^{-1}\right)$ & $0.066(0.051)$ & $0.068(0.802)$ & $4.239(1.180)$ & $0.540(0.266)$ & $0.048(0.049)$ \\
\hline Riffle $(\%)$ & $61(3)$ & $45(6)$ & $60(31)$ & $28(16)$ & $55(17)$ \\
\hline \multirow[t]{2}{*}{ Width (m) } & $4.1(1.2)$ & $5.0(2.2)$ & $12.5(2.3)$ & $12.3(2.7)$ & $3.4(1.0)$ \\
\hline & $23-37 \%$ & $17-44 \%$ & $13-22 \%$ & $20-24 \%$ & $13-52 \%$ \\
\hline \multirow[t]{2}{*}{ Open canopy (degrees) } & $23(19)$ & $35(21)$ & $95(10)$ & $98(13)$ & $50(26)$ \\
\hline & $22-190 \%$ & $0-126 \%$ & $9-27 \%$ & $11-31 \%$ & $15-166 \%$ \\
\hline \multirow[t]{2}{*}{ Riparian shade (\%) } & $89(10)$ & $80(15)$ & $67(18)$ & $72(26)$ & $86(10)$ \\
\hline & $1-81 \%$ & $3-43 \%$ & $24-79 \%$ & $7-70 \%$ & $4-36 \%$ \\
\hline \multirow[t]{2}{*}{ Depth (m) } & $0.17(0.03)$ & $0.21(0.10)$ & $0.72(0.03)$ & $0.44(0.06)$ & $0.15(0.03)$ \\
\hline & $69-95 \%$ & $64-96 \%$ & $25-34 \%$ & $56-90 \%$ & $44-99 \%$ \\
\hline \multirow[t]{2}{*}{ Water velocity $\left(\mathrm{m} \cdot \mathrm{s}^{-1}\right)$} & $0.16(0.07)$ & $0.13(0.07)$ & $0.83(0.12)$ & $0.22(0.09)$ & $0.14(0.06)$ \\
\hline & $112-147 \%$ & $70-377 \%$ & $35-55 \%$ & $70-95 \%$ & $76-290 \%$ \\
\hline \multirow[t]{2}{*}{ Dominant substrate $^{c}$} & $7.3(0.5)$ & $6.4(1.0)$ & $5.7(0.4)$ & $5.9(0.4)$ & $5.9(0.6)$ \\
\hline & $27-49 \%$ & $27-63 \%$ & $44-59 \%$ & $37-46 \%$ & $22-52 \%$ \\
\hline
\end{tabular}

The reach at Scorpion Gulch was $100 \mathrm{~m}$ long.

Elevation and gradient were only measured in 2004 for sites sampled in 2004 and 2005. Adjusted sample sizes for the groups are 3, 4, 2, 3, and 8, respectively 'Substrate categories: 1, smooth bedrock, concrete, hardpan; 2, silt, mud, or detritus; 3, sand ( $>0.063-2 \mathrm{~mm})$; 4, fine/medium gravel ( $>2-16 \mathrm{~mm})$; 5, coarse gravel $(>16-32 \mathrm{~mm})$; 6, very coarse gravel $(>32-64 \mathrm{~mm}) ; \mathbf{7}$, small cobble $(>64-128 \mathrm{~mm}) ; 8$, large cobble $(>128-256 \mathrm{~mm}) ; 9$, small boulder $(>256-512 \mathrm{~mm}) ; 10$, large gravel $(>16-32 \mathrm{~mm}) ; 6$, very coarse gravel $(>32-64 \mathrm{~mm}) ; 7$, small cobble $(>64-128 \mathrm{~mm}) ; 8$, large cobble
boulder, irregular bedrock, irregular hardpan, or irregular artificial surface (Fitzpatrick et al. 1998).

moved upstream through the study reach. Care was taken to not overlap areas where individual kick samples were taken.

Composite macroinvertebrate samples from both sampling methods were analyzed at the California Department of Fish and Game Aquatic Biological Assessment Laboratory (Chico, CA) or Rhithron Associates, Inc. (Missoula, MT). Processing was based on EPA-approved methods using a 500-organism count. Briefly, the sample is spread out in a gridded sampling pan and organisms in randomly selected grid cells are identified and counted. Grid cells are sampled until 500 organisms are counted and identified. Organisms were classified to the lowest practical taxon, usually genus for wellknown groups or some higher taxonomic designation for some of the lesser-known or difficult-to-identify taxa. Macroinvertebrate counts were converted to proportional abundance for statistical analysis.

We characterized habitat for each site according to Fitzpatrick et al. (1998). In short, we characterized habitat at each of the same 11 equally spaced transects used for the macroinvertebrate sampling. The transects were oriented perpendicular to stream flow. At each transect, we measured wetted channel width (m) with a fiberglass tape. Using a clinometer, we measured the arc of open sky $\left(0^{\circ}\right.$ to $\left.180^{\circ}\right)$ above the middle of the stream (open canopy). We measured streamside shading using a densitometer (\% canopy cover) at the left and right banks (riparian shading). At 3 points on each transect (maximum depth and 2 additional points approximating $0.25,0.50$, or 0.75 of the stream width), we measured stream depth ( $\mathrm{m}$, calibrated wading rod) and water velocity $\left(\mathrm{m} \cdot \mathrm{s}^{-1}\right.$, Marsh-McBirney Flo-mate 2000 electronic flow meter) and characterized the dominant substrate size (see Table 1 for substrate categories). Substrate was characterized visually with the aid of a ruler. We measured reach length and change in elevation using a surveying level and rod and then calculated stream gradient (\%) using the following expression: $(100 \times$ change in elevation across reach $) \div$ reach length. We visually estimated percentage area of riffle, run, and pool in the reach. Elevation of stream sites (m above sea level) was determined from topographical maps.

Water samples (2 L) were collected using a midstream grab method (Shelton 1994). One replicate sample and one equipment blank were collected during each year of the study 
period. Samples were analyzed for major ions (calcium, chloride, fluoride, iron, manganese, potassium, sodium, and sulfate) and trace metals (arsenic, barium, copper, manganese, selenium, and strontium) at the U.S. Geological Survey's National Water Quality Laboratory in Denver (NWQL), Colorado, or at the Murdock Environmental Geochemistry Laboratory at the University of Montana. At the NWQL, major ions were determined from filtered water samples using the methods of Hoffman et al. (1996), Garbarino and Struzeski (1998), and Fishman and Friedman (1989). Trace metals were also determined from filtered samples using the methods of Garbarino et al. (2006), Garbarino (1999), and Fishman and Friedman (1989). Samples analyzed for major ions and trace metals at the University of Montana's Environmental Biogeochemistry Laboratory utilized similar methods of analysis (USEPA Method 300.0; USEPA Method 6020). We compared our results to the "criterion continuous concentrations" (CCCs). A CCC is an estimate of the highest concentration of a material in surface water to which an aquatic community can be exposed indefinitely without an unacceptable effect, to determine if the observed concentrations could be affecting benthic macroinvertebrates (http://water.epa .gov/scitech/swguidance/standards/criteria/cur rent/index.cfm\#altable).

Bed sediment samples were collected for metals (arsenic, chromium, copper, lead, mercury, and zinc) analysis using methods described by Moore (2002) and Moore and Hughes (2003). Generally, one composite sample was collected per site. A composite sample consisted of sediment from 5-10 locations within the study reach. An effort was made to collect at locations spread throughout the reach, but fine sediments were not always available in equally spaced patches. Samples of fine-grain sediments were collected using a plastic spoon and were sieved through a 63um mesh nylon-sieve cloth directly into a sample jar. Sample collection and processing equipment were cleaned between each sampling site using methods described by Shelton and Capel (1994). At selected sites, composite samples were collected in triplicate to gauge variability of chemical concentrations. Samples were placed on dry ice and frozen prior to shipment to the Murdock Environmental Geochemistry Laboratory at the University of
Montana for chemical analyses. Samples were analyzed after a partial acid digestion to represent the portion of metals biologically available for uptake by organisms. Digested samples were analyzed for selected elements, including arsenic, chromium, copper, lead, and zinc, using Inductively Coupled Argon Plasma - Emission Spectroscopy (USEPA Method 200.7). Mercury was analyzed using Atomic Fluorescence Spectrometry (USEPA Method 245.7). We compared our results to consensus-based sediment quality guidelines for freshwater ecosystems (MacDonald et al. 2000) to determine if the observed concentrations could be affecting benthic macroinvertebrates. We compared both threshold effects concentration (TEC) and probable effects concentration (PEC). The TEC is intended to identify contaminant concentrations below which harmful effects on sediment-dwelling organisms are not expected. The PEC is intended to identify contaminant concentrations above which harmful effects on sediment-dwelling organisms are expected to occur frequently.

\section{Data Analysis}

We assessed patterns in benthic assemblage species composition using PRIMER v.6 software (Clarke and Gorley 2006). Benthic macroinvertebrate proportional abundance data were first square-root transformed to reduce the influence of abundant species. We then calculated a matrix of similarities among sites based on the Bray-Curtis similarity coefficient. We used these similarities for subsequent analyses. All analyses were conducted separately on TR and RW samples.

We first conducted a cluster analysis to identify samples that were similar to each other. We used the routine CLUSTER to conduct simple agglomerative, hierarchical clustering on the resemblance matrix, using the group-average option. We used SIMPROF to assess the statistical significance of the clusters. SIMPROF conducts permutation tests at each node of the cluster dendrogram to determine if the groups are statistically different $(P$ $<0.05)$. Cluster membership was used to define groups for subsequent data interpretation.

We then conducted nonmetric multidimensional scaling (NMS) (Kruskal 1964a, 1964b, Mather 1976, McCune and Grace 2002, Clarke and Gorley 2006) to identify gradients in 
species composition. NMS is an ordination technique similar in concept to other ordination techniques, such as principal components analysis or correspondence analysis. The "fit" of the ordination is assessed by the stress value. Conceptually, stress compares the original similarities between samples calculated from the full data matrix with the similarities calculated between samples in the lower dimension ordination space. Stress of $<0.20$ indicates that the lower dimension ordination successfully reproduces the patterns present in the higher dimension ordination space with minimal distortion (Clarke and Gorley 2006).

To better understand the distribution of samples and clusters in the NMS ordination space, we used the routine SIMPER and Spearman's rank correlation to identify the genera that were most responsible for high similarities within clusters and to identify the genera most responsible for high dissimilarities between clusters. Within groups, we considered genera responsible for $5 \%$ or more of the similarity within groups as possibly important. Between groups, we considered taxa responsible for $5 \%$ or more of the dissimilarity between groups as possibly important. We then correlated the abundances of these genera to NMS scores using Spearman's rank correlation $\left(r_{\mathrm{S}}\right)$ to determine the genera with close associations with NMS axes.

We used principal components analysis (PCA) to identify environmental gradients in habitat, water quality, and sediment quality that could potentially affect species distribution. A PCA analysis constructs independent (orthogonal) PCA axes that represent linear combinations of the original variables. We analyzed mean and coefficient of variation for transect-based habitat variables with multiple measurements per site. Water quality and sediment quality analyses included only major ions or metals detected at $>50 \%$ of the sites. For the sediment quality analysis, we calculated the mean of the triplicate samples, where taken. We examined normal probability plots and transformed data as needed to improve normality and homogeneity of variance. Only PCA axes with eigenvalues > 1 (Kaiser-Guttman criterion-Legendre and Legendre 1998) and explaining more than $10 \%$ of the variance were retained for interpretation and subsequent analyses.

We used the BEST procedure in PRIMER (Clarke and Gorley 2006) to identify relations of aquatic macroinvertebrate assemblages with habitat variables. BEST relates the patterns in assemblage composition summarized by NMS to an optimum set of environmental gradients (PCA axes). BEST is a multivariate permutation test that compares a matrix of Euclidean distances calculated from environmental measurements with the macroinvertebrate Bray-Curtis similarity matrix. A high correlation indicates a strong association of the species assemblage with the measured environmental variables. This analysis proceeds in a stepwise manner and tests all combinations of environmental variables to determine the best model. We conducted 1000 permutations of the procedure and selected the model with the highest Spearman's rank correlation and the fewest number of variables as the "best" model.

To assess stream biological condition in the upper Clear Creek drainage, we calculated IBI scores for each site using the Northern California IBI (Rehn et al. 2005). The metrics included in the IBI are the number of EPT (Ephemeropters, Trichoptera, and Plecoptera) taxa, number of Diptera taxa, \% intolerant individuals, \% non-gastropod scrapers, \% predator taxa, \% shredder taxa, and \% nonInsecta taxa. Metric scores were calculated by Andrew Rehn (California Department of Fish and Game) from the raw count data using a standard spreadsheet for calculation of IBI scores for the State of California. IBI scores were calculated for both TR and RW samples. The IBI scoring range is divided into 5 equal categories as follows: 0-20 = "very poor," 21-40 = "poor," 41-60 = "fair," 61-80= "good," and 81-100 = "very good." We then calculated correlations between the 2 scores. For sites sampled in both years, we also compared scores from the TR and RW with a paired $t$ test and compared between years within each sample type using a paired $t$ test.

\section{RESUlTs}

We collected a total of 236 genera of benthic macroinvertebrates. In the TR samples, 155 genera were collected in 2004 and 153 genera were collected in 2005 . In the RW samples, 194 genera were collected in 2004 and 176 genera were collected in 2005. Thus, slightly fewer genera were collected in the TR samples than were collected in the RW samples. 
Taxa richness of benthic macroinvertebrates ranged from 38 to 63 genera per site for the TR samples and from 41 to 68 genera per site for the RW samples. Taxa richness of both TR and RW macroinvertbrate assemblages were dominated by Ephemeroptera, Plecoptera, Trichoptera, and Diptera (primarily Chironomidae; Table 2). Coleoptera were also common in both sample types (Table 2).

Two dimensional ordinations gave similar and acceptable stress values for both sample types (TR samples, stress $=0.17$; RW samples, stress $=0.18)$. The cluster analyses and ordinations of benthic macroinvertebrate samples gave very similar results for TR and RW samples. There were 10 statistically different site clusters in the TR data (Fig. 2) and 9 in the RW data (Fig. 3). There were 6 samples from 5 TR sites (Fig. 2) and 5 samples from 3 RW sites (Fig. 3) that did not cluster with any other site. For both sample types, the Clear Creek samples from below the dam clustered separately from the samples from upstream of the reservoir. The samples from the upper elevation sites (1570-2408 m) of Boulder Creek, Crystal Creek, and Brandy Creek tended to be located together in the same area of the plot. Samples from the lower-elevation sites (1284$1350 \mathrm{~m}$ ) on those streams and the other lowelevation sites were generally located in the middle area of the plots (Figs. 2, 3).

There were 60 genera considered common in the study (Table 2). A genus was considered common if it occurred in more than half of the samples in one year in one of the sample types. The SIMPER analysis identified 16 genera that accounted for more than $5 \%$ of the similarities and dissimilarities between RW clusters and 22 genera for TR clusters (Table 2 ). Twelve of these genera were common to both sample types (Table 2). Based on correlations of absolute value 0.5 or greater $(P<0.01$ for all), NMS axis 1 from both sample types indicated a major gradient extending from samples dominated by Micropsectra (Diptera) and Baetis (Ephemeroptera) at negative values of NMS axis 1 to samples dominated by Torrenticola (Trombidiformes) and Helicopsyche (Trichoptera) at positive values of NMS axis 1 (Figs. 2, 3). For the RW samples, Zapada (Plecoptera) were also abundant at negative values of NMS axis 1. For the TR samples, higher abundances of Zaitzevia (Coleoptera) were associated with positive values of NMS axis 1 .

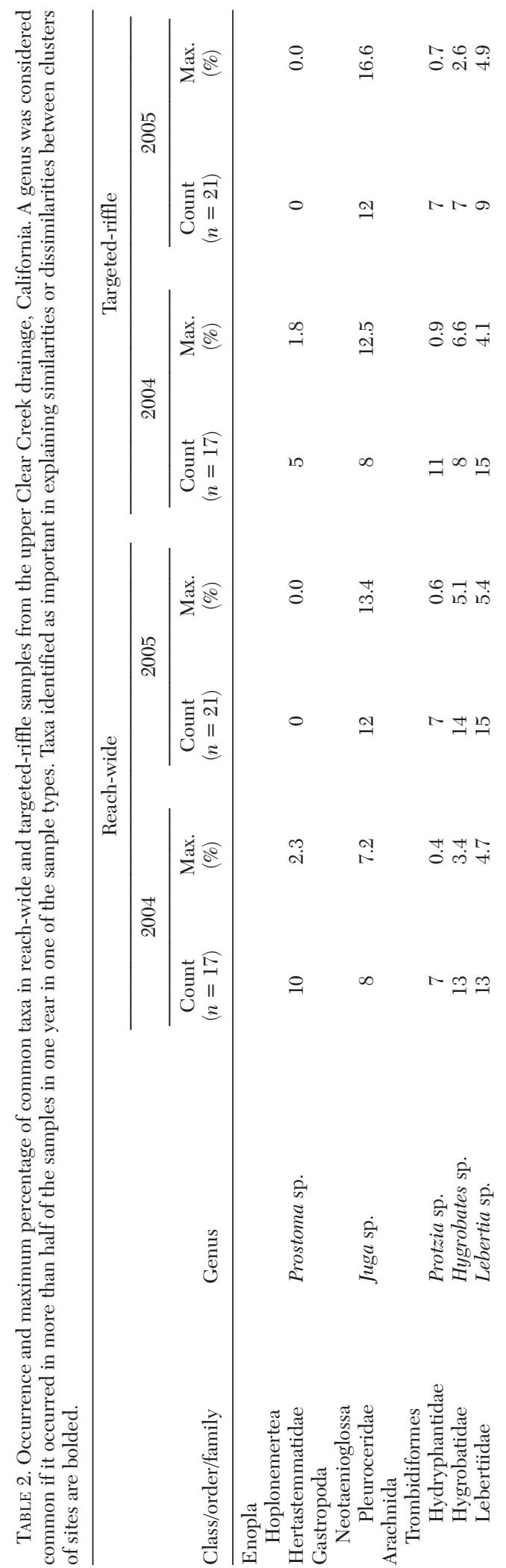




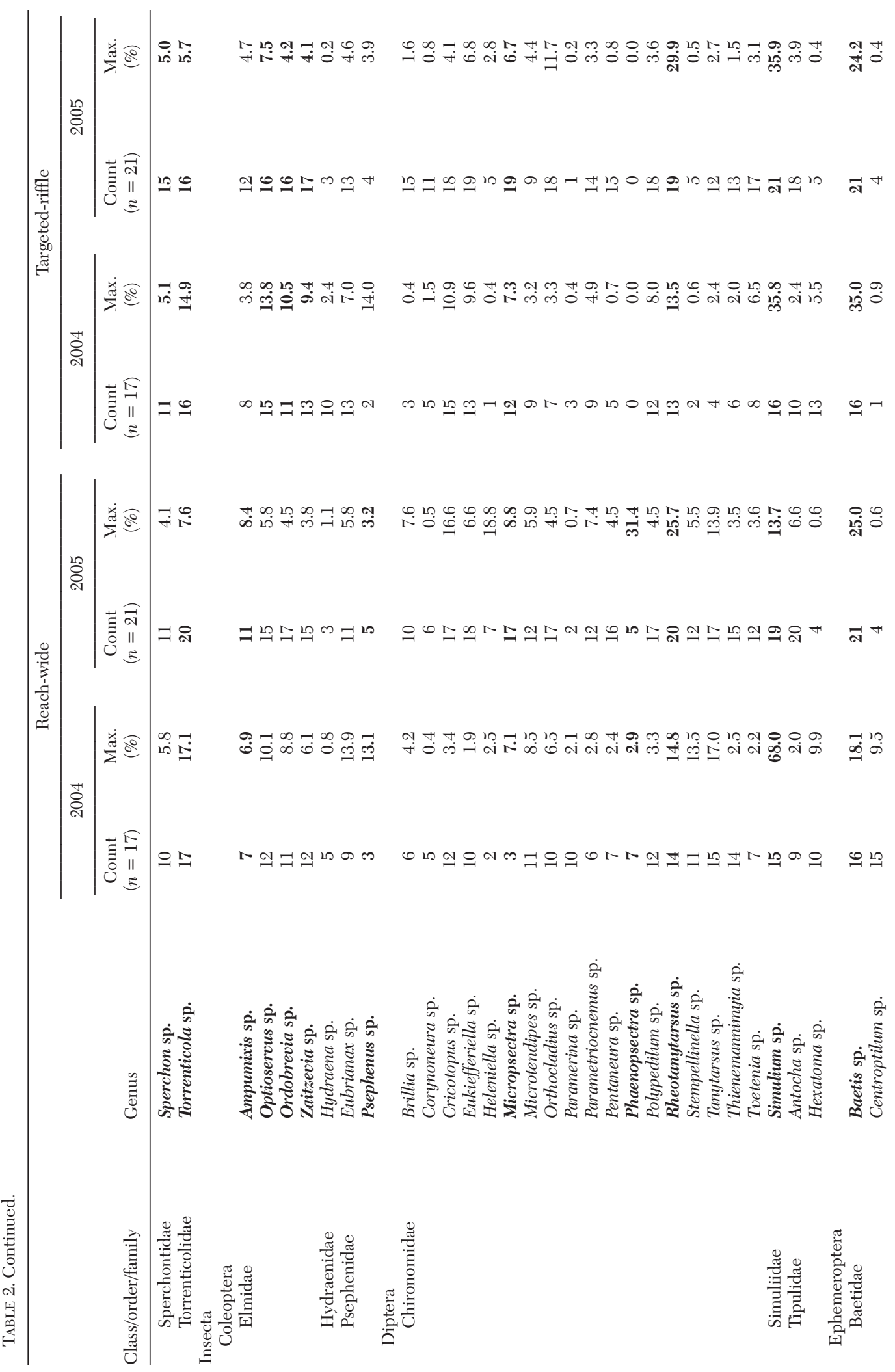




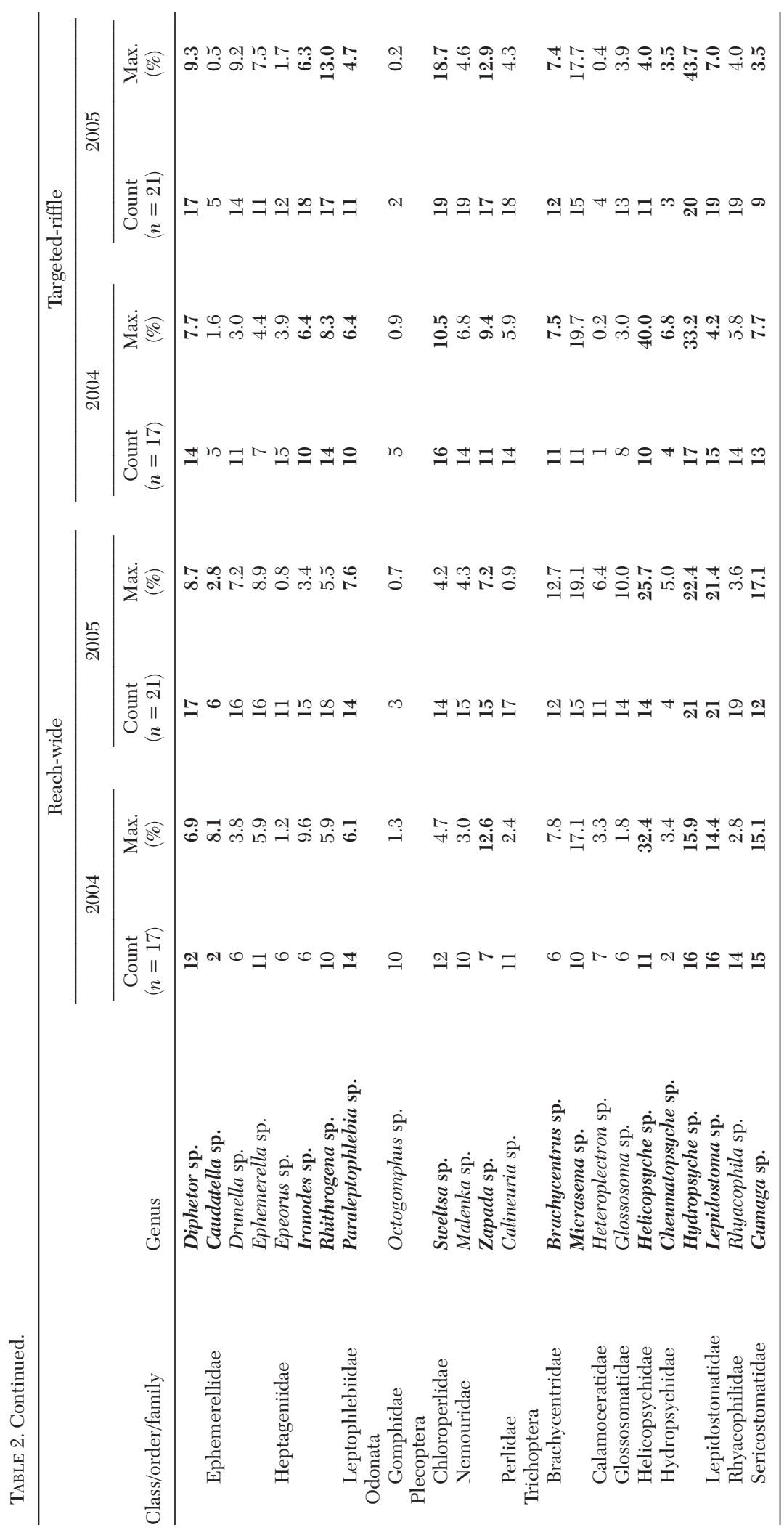




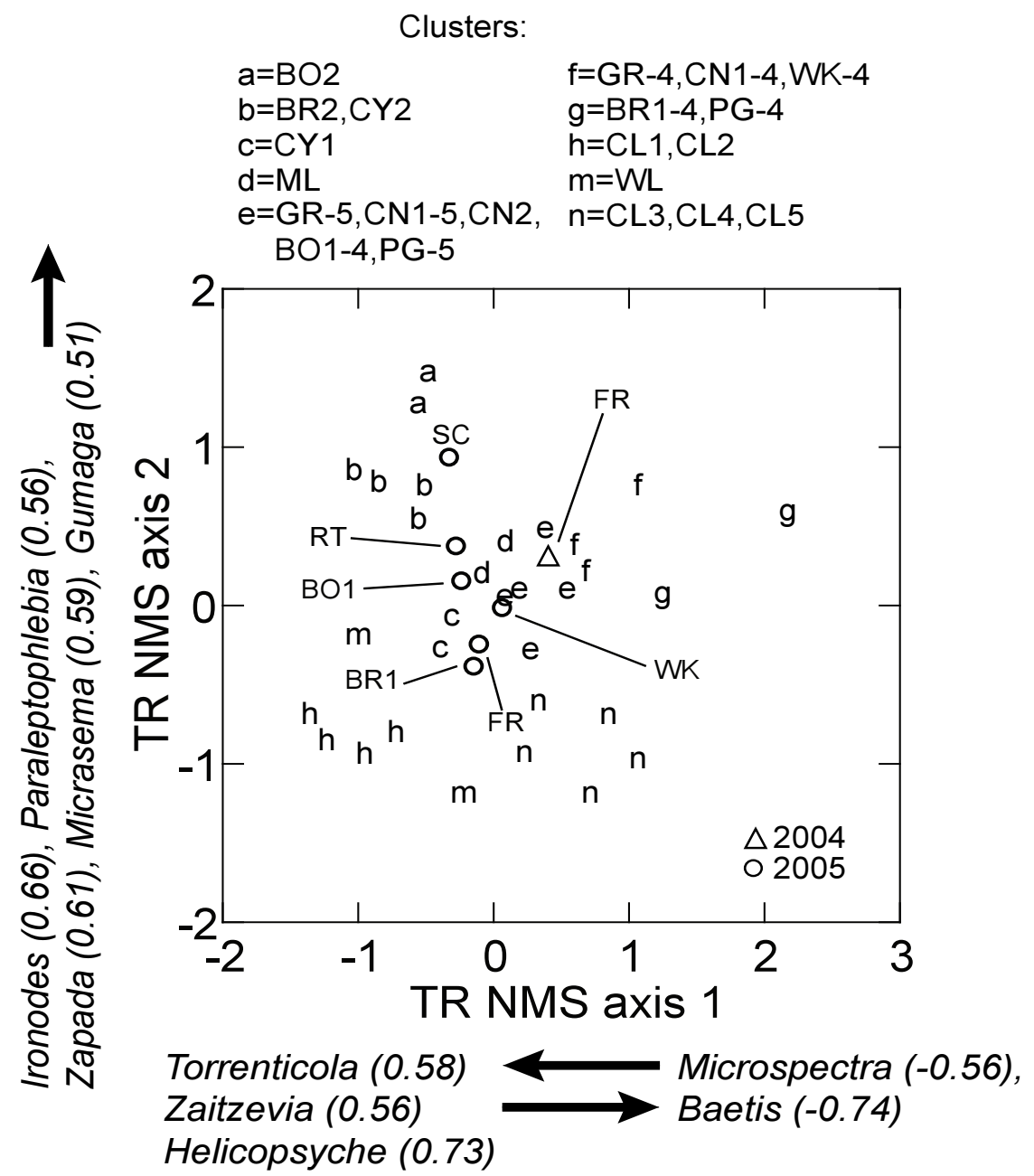

Fig. 2. Plot of ordination scores from nonmetric multidimensional scaling (NMS) analysis of aquatic macroinvertebrate percentage abundances for targeted-riffle (TR) habitat samples from upper Clear Creek watershed, California, in fall 2004 and 2005. Lowercase letters indicate statistically different $(P<0.05)$ clusters. Sites that did not cluster with others are shown separately. Refer to Fig. 1 for site locations. Arrows indicate the direction of increasing species abundance for species with statistically significant $(P<0.01)$ Spearman's rank correlations. Correlation coefficients are shown in parentheses. In the cluster descriptions, 2004 and 2005 samples from a site were identified by the suffix -4 or -5 , respectively, when samples were split between clusters.

Based on correlations of absolute value 0.5 or greater, increasing values of NMS axis 2 were associated with increasing abundances of Paraleptophlebia (Ephemeroptera) and Gumaga (Trichoptera) for both sample types (Figs. 2, 3). In addition, the TR samples Ironodes (Ephemeroptera), Zapada (Plecoptera), and Micrasema (Trichoptera) also had higher abundance at higher values of NMS axis 2 .

The streams sampled in this study presented aquatic organisms with a wide array of environmental conditions (Table 1). The upper sites on the southern streams were at the highest elevations, had the steepest gradients and coarsest substrates, and were dominated by riffle habitat. These characteristics were greatly different from the mainstem Clear Creek sites, which had the lowest gradients, finer substrates, and the widest and deepest sites. The influences of reservoir releases on the lower Clear Creek sites were evident in flow, dominance of riffles, depth, and water velocity. The lower southern streams and northern streams were generally similar in physical conditions (Table 1). 


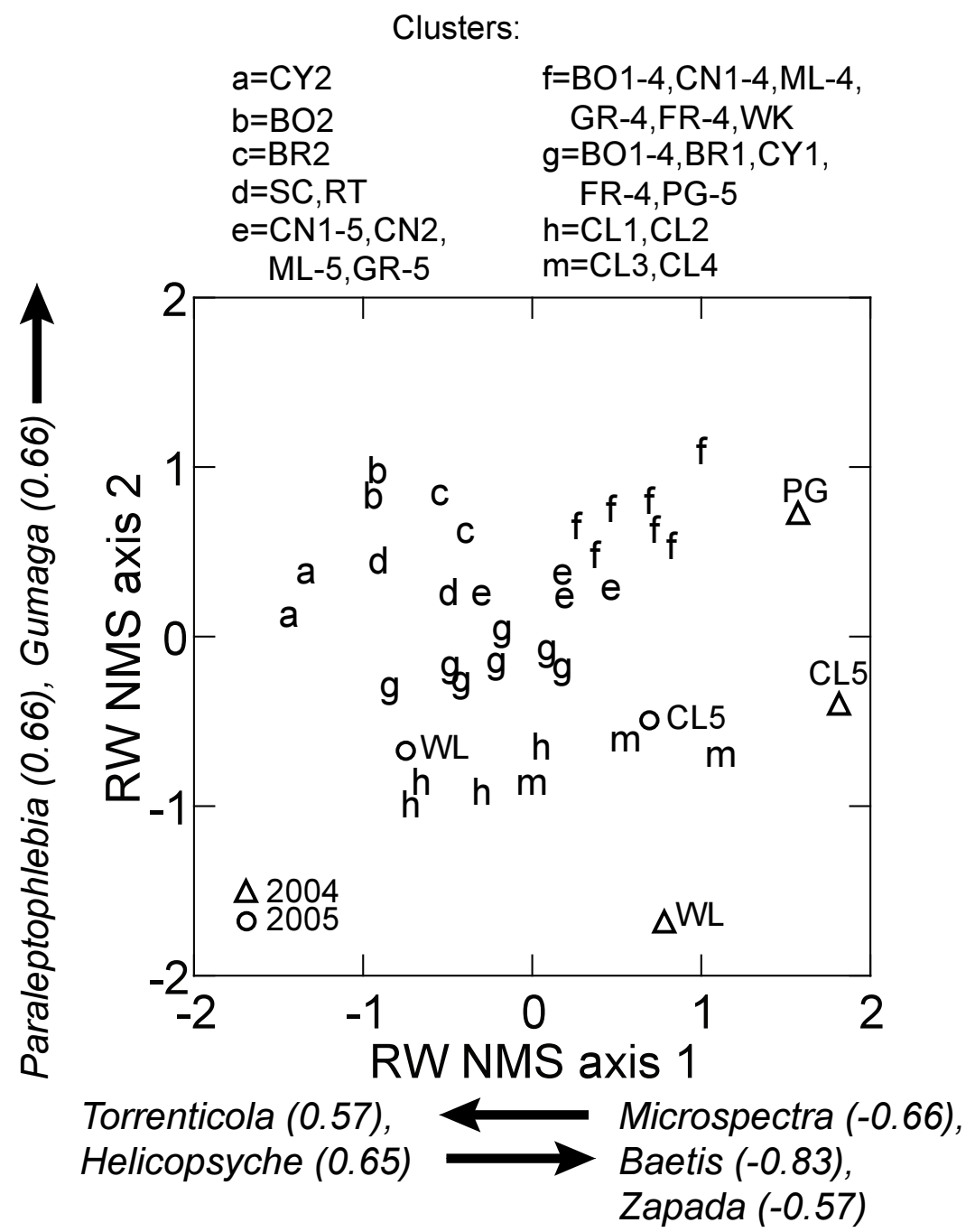

Fig. 3. Plot of ordination scores from nonmetric multidimensional scaling (NMS) analysis of aquatic macroinvertebrate percentage abundances for reach-wide (RW) habitat samples from upper Clear Creek watershed, California, in fall 2004 and 2005. Lowercase letters indicate statistically different $(P<0.05)$ clusters. Sites that did not cluster with others are shown separately. Refer to Fig. 1 for site locations. Arrows indicate the direction of increasing species abundance for species with statistically significant $(P<0.01)$ Spearman's rank correlations. Correlation coefficients are shown in parentheses. In the cluster descriptions, 2004 and 2005 samples from a site were identified by the suffix -4 or -5 , respectively, when samples were split between clusters.

The PCA analysis of habitat data identified 5 PCA axes with eigenvalues $>1$ that explained $83 \%$ of the variance in the habitat data; however, only 3 of the PCA axes individually explained greater than $10 \%$ of the variance. The first 2 PCA axes explained $36 \%$ and $16 \%$, respectively, and described 2 major gradients in habitat conditions (Fig. 4). The gradient represented by PCA axis 1 (HAB1) was associated with a suite of variables related to stream size, and the gradient represented by PCA axis 2 (HAB2) was associated with a suite of variables related to riffle habitat (Fig. 4). The mainstem Clear Creek sites were clearly different from the others on PCA axis 1, with the lower Clear Creek sites the largest because of water releases from the reservoir. Riffles tended to dominate the more upstream sites of the smaller streams (PCA axis 2) and the lower Clear Creek sites. The third habitat 


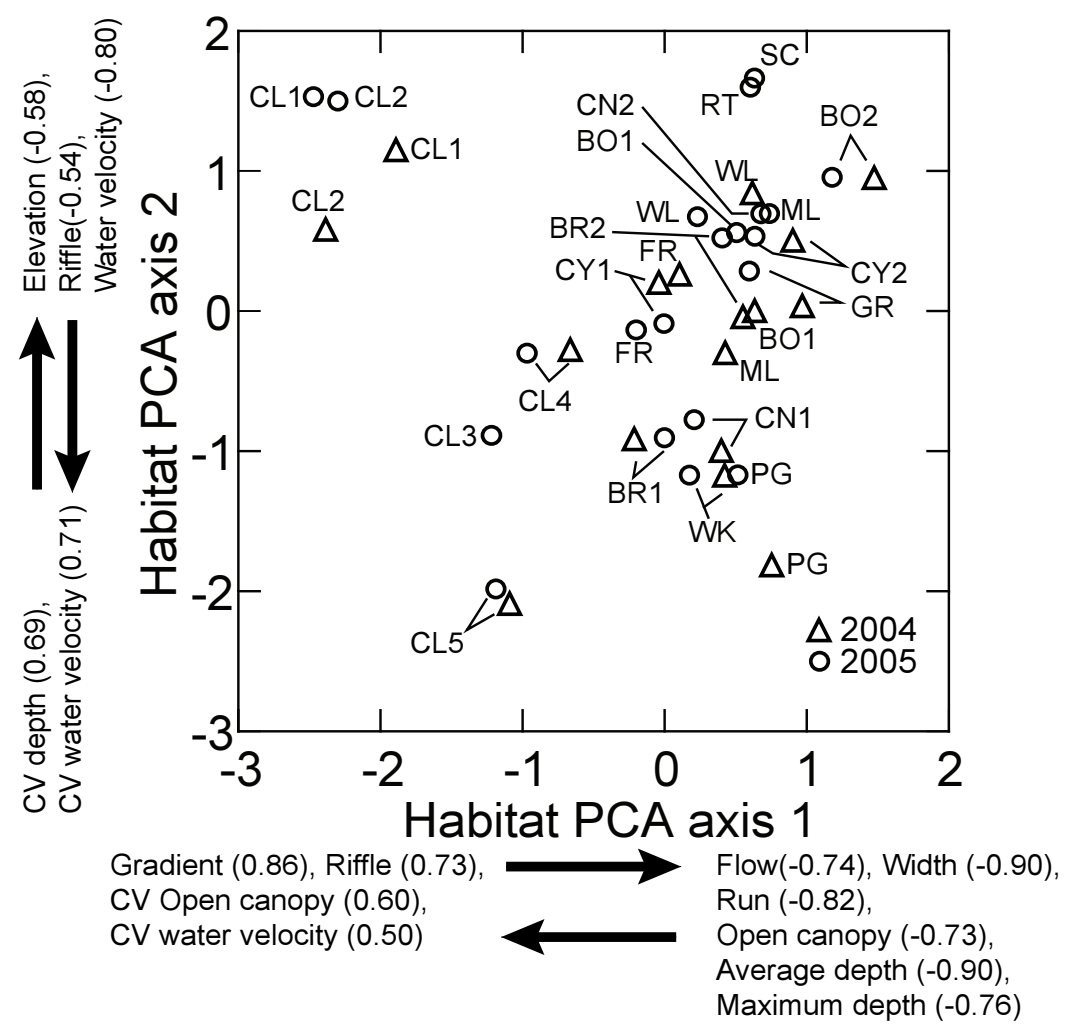

Fig. 4. Site scores on the first 2 axes of a principal components analysis (PCA) of habitat data from upper Clear Creek watershed, California, in fall 2004 and 2005. Arrows indicate the direction of increase on each PCA axis for individual variables with factor loadings with absolute value $>0.5$. Factor loadings are given in parentheses. Refer to Fig. 1 for site locations.

PCA axis (HAB3) explained $11 \%$ of the variance and was mainly associated with substrate size, coefficient of variation $(\mathrm{CV})$ of substrate size, and pool habitat.

Water quality in the study area was variable, with many concentrations differing by 10-fold or more among sites (Table 3). Dissolved ions and metals were generally highest in streams in the northern portion of the study area with historical or active mining. Of the metals most likely to have ecological importance, Willow Creek (WL) had the highest concentrations of copper $\left(10.8 \mu \mathrm{g} \cdot \mathrm{L}^{-1}\right)$. Scorpion Gulch (SC) had the highest concentrations of selenium $\left(0.98 \mu \mathrm{g} \cdot \mathrm{L}^{-1}\right)$, and French Gulch (2004) had the highest concentration of arsenic $\left(44.2 \mu \mathrm{g} \cdot \mathrm{L}^{-1}\right)$. Only copper at Willow Creek in 2005 exceeded the CCC.

The PCA analysis of water quality data identified 3 PCA axes with eigenvalues $>1$ that explained $82 \%$ of the variance in the water quality data. The first 2 PCA axes explained $52 \%$ and $19 \%$ of variance, respectively, and described 2 major gradients in water quality conditions (Fig. 5). The major gradient (WQ1) was associated with generally high concentrations of major ions and trace elements, except for potassium. Concentrations tended to be low in southern streams, including Brandy Creek, Boulder Creek, Crystal Creek, Mill Creek, Paige-Boulder Creek, and Clear Creek below the reservoir. Concentrations were highest in Willow Creek. The second PCA axis (WQ2) identified a positive correlation between concentrations of potassium, sodium, and chloride (Fig. 5). Samples from Willow Creek and Paige-Boulder Creek (2004) had high concentrations of potassium, sodium, and chloride. The third water quality PCA axis (WQ3) explained $11 \%$ of the variance and identified an inverse correlation of manganese (unfiltered sample) and strontium. The sites 
TABLE 3. Frequency of detection, mean (SD), and range for concentrations of major ions and metals in water and sediment samples from 38 sites in the upper Clear Creek watershed, California, in fall 2004 and 2005.

\begin{tabular}{|c|c|c|c|}
\hline Variable & $\begin{array}{l}\text { Frequency of } \\
\text { detection }(\%)\end{array}$ & Mean $(\mathrm{SD})^{\mathrm{a}}$ & Range \\
\hline \multicolumn{4}{|l|}{ Water quality analysis } \\
\hline Calcium $\left(\mathrm{Ca}, \mathrm{mg} \cdot \mathrm{L}^{-1}\right)^{\mathrm{b}}$ & 100 & $11.49(7.11)$ & $4.49-32.25$ \\
\hline Chloride $\left(\mathrm{Cl}, \mathrm{mg} \cdot \mathrm{L}^{-1}\right)^{\mathrm{c}}$ & 100 & $4.02(10.94)$ & $0.21-49.54$ \\
\hline Flouride $\left(\mathrm{F}, \mathrm{mg} \cdot \mathrm{L}^{-1}\right)^{\mathrm{c}}$ & 55 & $0.06(0.04)$ & $<0.04-0.16$ \\
\hline $\operatorname{Iron}\left(\mathrm{Fe}, \mu \mathrm{g} \cdot \mathrm{L}^{-1}\right)^{\mathrm{b}}$ & 89 & $130.70(456.11)$ & $<4.60-2298.00$ \\
\hline $\operatorname{Magnesium}\left(\mathrm{Mg}, \mathrm{mg} \cdot \mathrm{L}^{-1}\right)^{\mathrm{b}}$ & 100 & $3.59(2.15)$ & $0.98-8.39$ \\
\hline Manganese $\left(\mathrm{Mn}, \mathrm{mg} \cdot \mathrm{L}^{-1}\right)^{\mathrm{b}}$ & 97 & $4.79(7.51)$ & $<0.16-30.49$ \\
\hline $\operatorname{Potassium}\left(\mathrm{K}, \mathrm{mg} \cdot \mathrm{L}^{-1}\right)^{\mathrm{b}}$ & 100 & $0.69(0.51)$ & $0.17-2.21$ \\
\hline Sodium $\left(\mathrm{Na}, \mathrm{mg} \cdot \mathrm{L}^{-1}\right)^{\mathrm{b}}$ & 100 & $5.65(5.14)$ & $1.86-30.67$ \\
\hline Sulfate $\left(\mathrm{SO}_{4}, \mathrm{mg} \cdot \mathrm{L}^{-1}\right) \mathrm{c}$ & 100 & $9.61(12.81)$ & $0.25-58.85$ \\
\hline $\mathrm{pH}$ & 100 & $7.54(0.26)$ & $6.71-7.96$ \\
\hline Specific conductance $\left(\mu \mathrm{S} \cdot \mathrm{cm}^{-1}\right)$ & 100 & $120(70)$ & $58-379$ \\
\hline Arsenic $\left(\right.$ As, $\left.\mu \mathrm{g} \cdot \mathrm{L}^{-1}\right) \mathrm{d}$ & 95 & $3.248(6.128)$ & $<0.022-25.880$ \\
\hline $\operatorname{Barium}\left(\mathrm{Ba}, \mu \mathrm{g} \cdot \mathrm{L}^{-1}\right) \mathrm{d}$ & 37 & $16.865(11.677)$ & $4.478-43.531$ \\
\hline Copper $\left(\mathrm{Cu}, \mu \mathrm{g} \cdot \mathrm{L}^{-1}\right)^{\mathrm{d}}$ & 71 & $1.371(2.039)$ & $<0.5-10.762$ \\
\hline Manganese $\left(\mathrm{Mn}, \mu \mathrm{g} \cdot \mathrm{L}^{-1}\right) \mathrm{d}$ & 95 & $2.524(4.652)$ & $0.140-24.892$ \\
\hline Selenium $\left(\mathrm{Se}, \mu \mathrm{g} \cdot \mathrm{L}^{-1}\right)^{\mathrm{d}}$ & 71 & $0.179(0.200)$ & $<0.030-0.983$ \\
\hline Strontium $\left(\mathrm{Sr}, \mu \mathrm{g} \cdot \mathrm{L}^{-1}\right) \mathrm{d}$ & 100 & $64.016(37.750)$ & 20.093-169.580 \\
\hline \multicolumn{4}{|l|}{ Sediment quality analysis } \\
\hline Arsenic $\left(\mathrm{As}, \mathrm{mg} \cdot \mathrm{kg}^{-1}\right) \mathrm{e}$ & 84 & $40.229(77.225)$ & $<2.500-417.146$ \\
\hline Chromium $\left(\mathrm{Cr}, \mathrm{mg} \cdot \mathrm{kg}^{-1}\right) \mathrm{e}$ & 100 & $50.994(20.000)$ & 28.885-117.139 \\
\hline Copper $\left(\mathrm{Cu}, \mathrm{mg} \cdot \mathrm{kg}^{-1}\right) \mathrm{e}$ & 100 & $93.190(206.118)$ & $3.050-1190.000$ \\
\hline Lead $\left(\mathrm{Pb}, \mathrm{mg} \cdot \mathrm{kg}^{-1}\right) \mathrm{e}$ & 100 & $29.090(14.854)$ & $14.770-94.766$ \\
\hline $\operatorname{Mercury}\left(\mathrm{Hg}, \mathrm{mg} \cdot \mathrm{kg}^{-1}\right)^{\mathrm{e}}$ & 100 & $0.299(0.418)$ & $0.030-1.664$ \\
\hline $\operatorname{Zinc}\left(\mathrm{Zn}, \mathrm{mg} \cdot \mathrm{kg}^{-1}\right) \mathrm{e}$ & 100 & $199.681(221.187)$ & $38.720-1224.000$ \\
\hline
\end{tabular}

sharing the southern granitic geology grouped relatively tightly with low scores on PCA axis 1 and moderate scores on PCA axis 2. The 2004 sample for Paige-Boulder Creek was somewhat of an extreme value. The sites sharing the northern, mixed geology tended to form 2 groups, mainly differing along PCA axis 2, with Willow Creek having the most extreme values. The lower Clear Creek sites are intermediate likely because of dilution by tributary streams (CL3) and mixing with Trinity River water in the reservoir (CL1 and CL2).

Similar to dissolved constituents, concentrations of metals in sediments (Table 3) were highest in northern streams with historical or active mining. Willow Creek (WL) had the highest levels of both copper $(1190.0 \mathrm{mg}$. $\mathrm{kg}^{-1}$ ) and zinc $\left(1224.0 \mathrm{mg} \cdot \mathrm{kg}^{-1}\right)$. Scorpion Gulch (SC) had the highest concentrations of arsenic (440.2 $\mathrm{mg} \cdot \mathrm{kg}^{-1}$ ), mercury (2.75 mg • $\left.\mathrm{kg}^{-1}\right)$, and lead $\left(133.0 \mathrm{mg} \cdot \mathrm{kg}^{-1}\right)$. TEC values were generally exceeded for arsenic, copper, lead, mercury, and zinc in the northern streams and mainstem Clear Creek, including sites below the dam. Chromium exceeded TEC values in both southern and northern streams. TEC exceedances only suggest a potential for biological effects. PEC exceedances, indicating probable effects on sedimentdwelling organisms, primarily occurred in northern streams and mainstem sites above the reservoir. The arsenic PEC was exceeded in mainstem Clear Creek (CL3), Cline Gulch, French Gulch, Right Gulch, Scorpion Gulch, and Willow Creek (2004). The chromium PEC was exceeded only in Paige-Boulder Creek. The copper PEC was exceeded in mainstem Clear Creek (CL3) and Willow Creek. The mercury PEC was exceeded in Cline Creek (CN2), French Gulch (2004), and Scorpion Gulch. The zinc PEC was exceeded in Whiskey Creek and Willow Creek.

The PCA analysis of sediment quality data identified 2 PCA axes that explained $83 \%$ of the variance in the sediment data (Fig. 6). The major gradient (SED1) explained $66 \%$ of the variance and identified a pattern of increasing concentrations of arsenic, copper, mercury, 


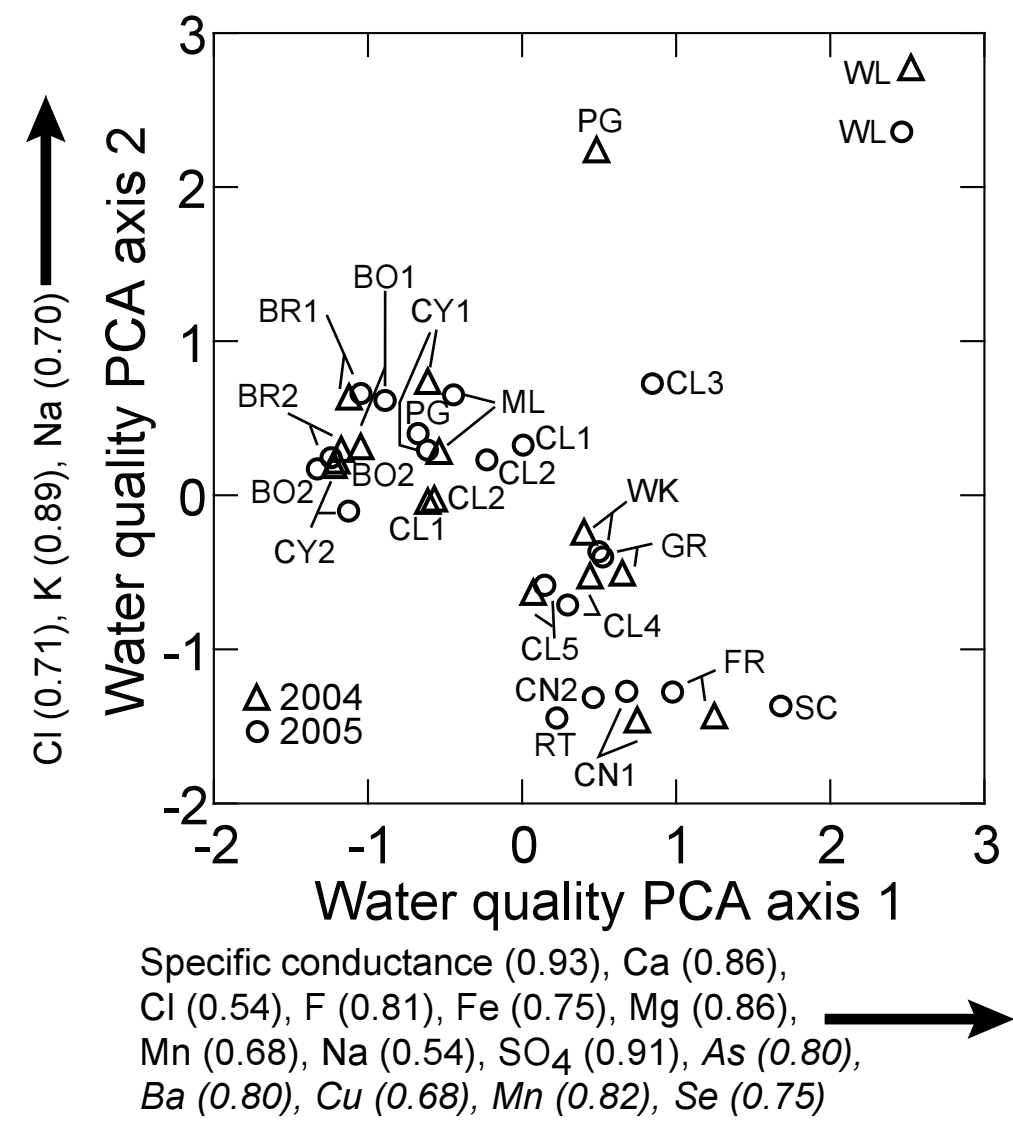

Fig. 5. Site scores on the first 2 axes of a principal components analysis (PCA) of water quality data from upper Clear Creek watershed, California, in fall 2004 and 2005. Arrows indicate the direction of increase on each PCA axis for individual variables with factor loadings with absolute value $>0.5$. Factor loadings are given in parentheses. Refer to Fig. 1 for site locations. Italics indicate concentrations of metals in filtered, acidified samples. See Table 4 for chemical abbreviations.

lead, and zinc, with decreasing concentrations of chromium. Boulder, Brandy, Crystal, and Paige-Boulder creeks tended to have low concentrations of arsenic, copper, mercury, lead, and zinc and high concentrations of chromium, while Willow Creek, Whiskey Creek, Scorpion Gulch, Cline Gulch, and French Gulch tended to have the opposite pattern. The second gradient (SED2) explained $17 \%$ of the variance and identified a positive correlation between concentrations of chromium and copper. Willow Creek did not have an extreme value for sediment concentrations as it did for dissolved constituents. The group of sites including Cline Gulch, French Gulch, Scorpion Gulch, and Right Gulch is identical to the group in the lower right of the water quality plot.

The multivariate BEST models indicated that the 2 types of samples responded to envi- ronmental gradients in similar ways. The best single factor model for TR macroinvertebrates included HABl $\left(r_{\mathrm{s}}=0.47\right)$. The best multiple factor model included HAB1, HAB2, and WQ1 $\left(r_{\mathrm{s}}=0.60, P<0.001\right)$. The best single factor model for RW macroinvertebrates included HABI $\left(r_{\mathrm{s}}=0.33\right)$. The best multiple factor model included HAB1, HAB2, and WQ1 $\left(r_{\mathrm{s}}=0.50, P<0.001\right)$, the same model derived from the TR samples. The BEST results suggest that environmental conditions associated with stream size (HAB1), abundance of riffles (HAB2), and concentrations of dissolved substances (WQ1) are the most biologically relevant environmental gradients.

The Northern California IBI generally scored sites as ranging from fair to very good in relation to biological condition (Fig. 7), except for the Willow Creek site, which was 


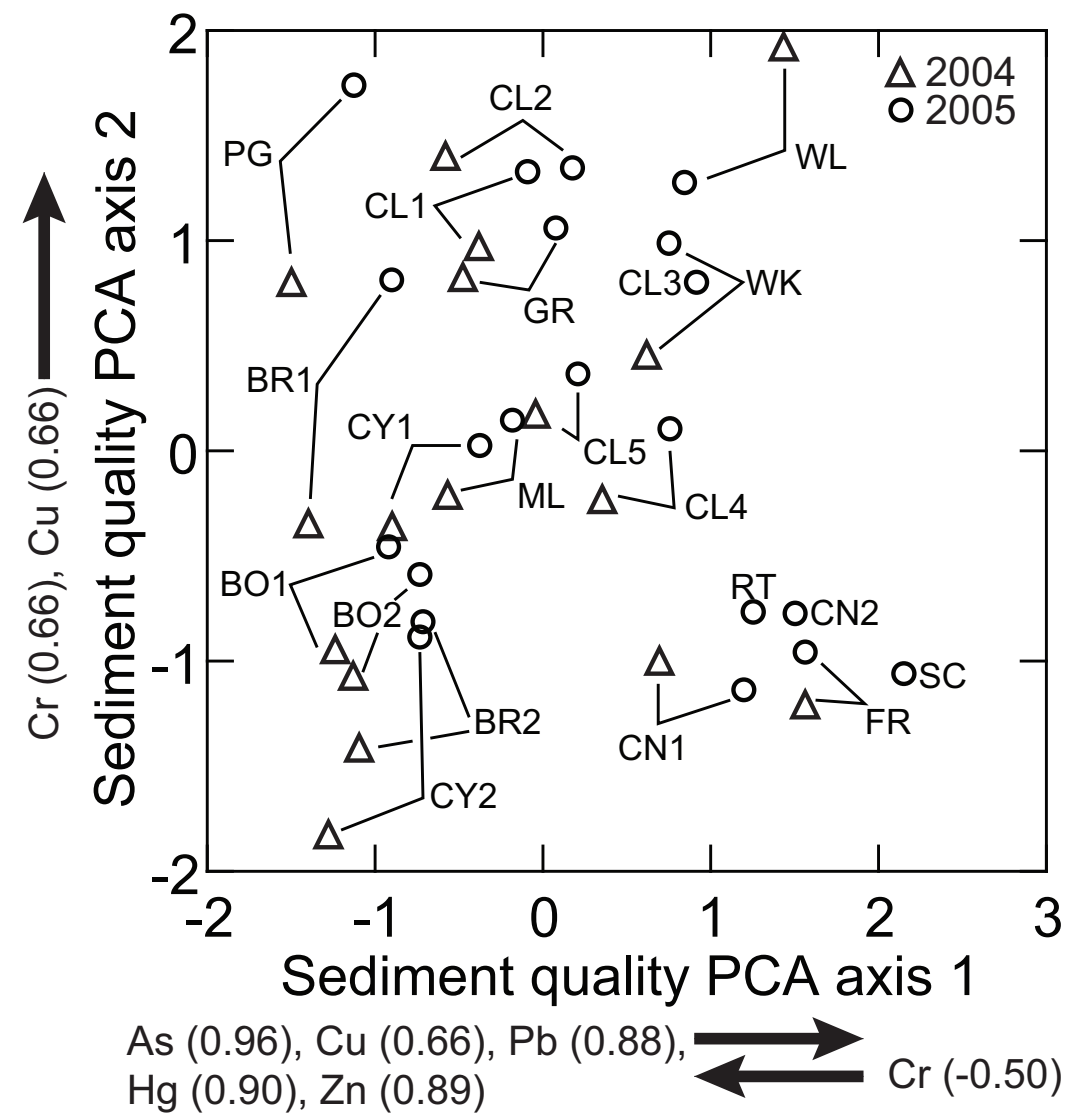

Fig. 6. Site scores on the first 2 axes of a principal components analysis (PCA) of sediment quality data from upper Clear Creek watershed, California, in fall 2004 and 2005. Arrows indicate the direction of increase on each PCA axis for individual variables with factor loadings with absolute value $>0.5$. Factor loadings are given in parentheses. Refer to Fig. 1 for site locations. See Table 4 for chemical abbreviations.

rated as poor in 2004 based on the RW sample. The RW sample tended to classify sites as good (Fig. 7). The ratings of very good based on the TR samples were at the upper-elevation sites in Boulder (2004), Brandy (2005), and Crystal (both years) creeks and at low-elevation sites on Mill Creek (2004), Whiskey Creek (2004), Scorpion Gulch and Cline Gulch (2005). Ratings of fair based on TR samples but good based on RW samples included lower Boulder Creek (2005), Clear Creek (CL1 and CL5, 2005), and upper Cline Gulch. The correlation between the 2 IBI scores was significant $\left(r_{\mathrm{S}}=0.71\right)$. The mean IBI score $( \pm \mathrm{SD})$ was $68 \pm 11$ for the TR samples and 66 \pm 12 for the RW samples. Ranges were 50-86 and 33-91, respectively. A paired $t$ test showed no statistically significant difference between IBI scores from the different sample types. The mean difference between scores for the sample types was 1.7 points. There was no statistical difference between years in mean score for RW samples (paired $t$ test, $P>0.05$ ), but there was a difference for TR samples (paired $t$ test, $P<0.05$ ).

\section{DISCUSSION}

The first objective of this study was to document the benthic macroinvertebrate assemblages supported by streams in the upper Clear Creek area. The streams of the region provide habitat for a diverse array of aquatic benthic macroinvertebrates; however, the taxa observed were not unusual for California streams. Many of the same families and common genera collected in this study have been collected by other studies in the region (e.g., 


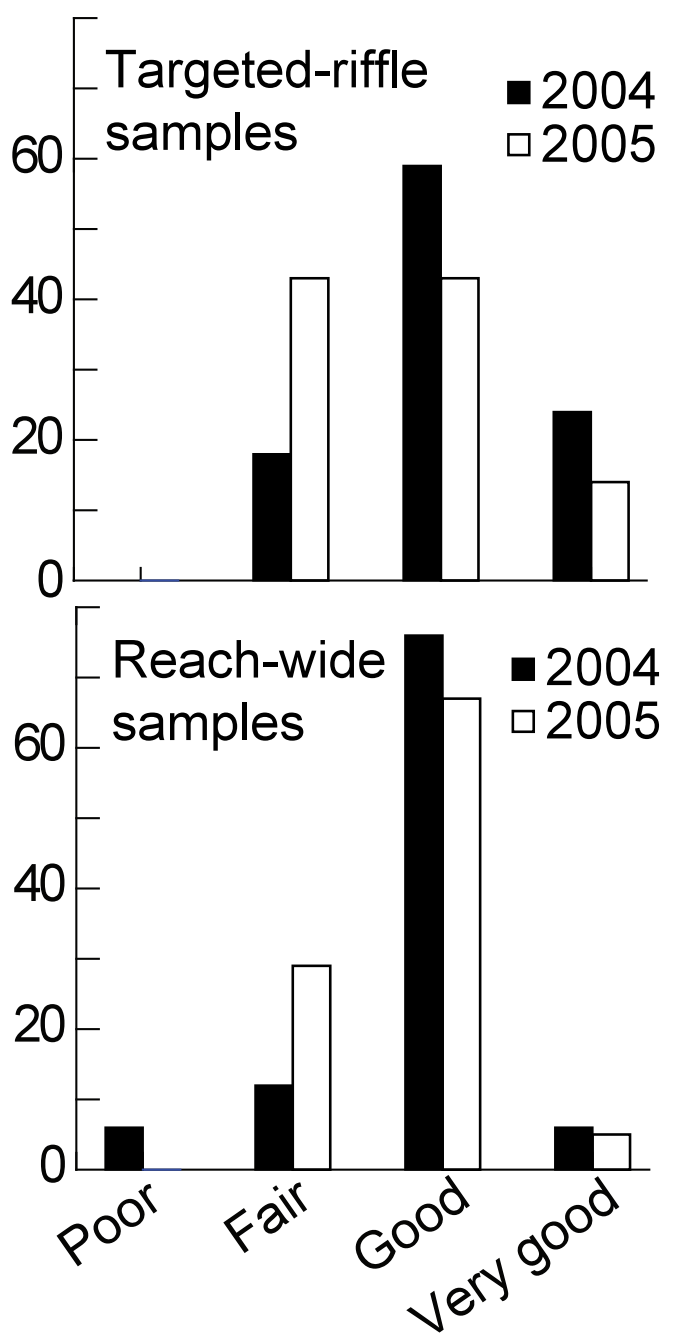

Fig. 7. Percentages of sites in poor, fair, good, or very good condition based on the Northern California Index of Biotic Integrity for reach-wide (RW) and targeted-riffle (TR) samples from the upper Clear Creek watershed, California, in fall 2004 and 2005.

Bonada et al. 2006, Bêche and Resh 2007). Within the study area, the results of the cluster and NMS analyses (Figs. 2, 3) suggest that these commonly occurring taxa combined into relatively distinctive assemblages of benthic macroinvertebrates. The assemblages of the mainstem Clear Creek formed separate clusters from the other streams, and within Clear Creek, the assemblages from above and below the reservoir formed separate clusters. The higher-elevation and higher-gradient sites on the southern streams cluster separately from the northern streams and the lower-elevation sites on the southern streams. In general, assemblages at the same site were similar in 2004 and 2005, especially at the Clear Creek and the upper southern stream sites. The most notable difference between years was for Paige-Boulder Creek, which we suspect may have become intermittent for some period in 2004. The flow at the time of sampling was very low $\left(<0.001 \mathrm{~m}^{3} \cdot \mathrm{s}^{-1}\right)$. The relatively high ionic content of the water supports the hypothesis of intermittency, assuming that evaporation would concentrate dissolved substances in isolated pools, a general pattern in Mediterranean-climate streams (Gasith and Resh 1999). Annual variation in stream flow, especially related to droughts and floods, is known to have strong effects on benthic macroinvertebrate assemblages in northern California streams (Bêche and Resh 2007, Power et al. 2008, Bêche et al. 2009). Shifts between intermittent and perennial conditions in a stream can also have strong effects on assemblage structure (Bonada et al. 2006).

The common aquatic macroinvertebrates associated with the NMS axes (Figs. 2,3) represent a variety of environmental preferences and tolerances (Vieira et al. 2006). The genera associated with NMS 1 represent a contrast between taxa associated with swift, cool, riffledominated streams and taxa associated with wider, deeper, lower-gradient streams. Baetis, Micropsectra, and Zapada are one co-occurring group associated with NMS 1. Mayflies of the genus Baetis are good swimmers (Vieira et al. 2006) and are common in small streams with fast currents and abundant riffles. Mayflies of this genus are often the dominant mayfly in the stressful environments of high mountain streams or springs and are tolerant of mild pollution (Ward and Kondratieff 1992). The plecopteran genus Zapada, like other plecopteran genera, is associated with cold, highly oxygenated streams (Ward and Kondratieff 1992, Vieira et al. 2006). Similarly, the chironomid Micropsectra is generally found in smaller streams. As these genera decline, Helicopsyche, Zaitzevia, and Torrenticola increase. These genera appear to be more habitat generalists in comparison. Helicopsyche is a casebuilding, grazing caddisfly genus that is known to have important effects on periphyton in northern California streams (Feminella et al. 1989). Helicopsyche is tolerant of warm 
temperatures and can be found in small streams, rivers, and low velocity waters, including lake margins (Vieira et al. 2006). Torrenticola, a genus of water mites, is not well studied but has been found in a wide variety of habitats (Vieira et al. 2006). The coleopteran genus Zaitzevia is also poorly known but is generally associated with riffle habitat. Some species of the genus are adapted to warm springs, so the association with the other 2 genera may be related to temperature or some other factor besides gross habitat preferences.

The common genera associated with NMS 2 are generally associated with cool, high-gradient, riffle-dominated sites. Ironodes is a flattened ephemeropteran adapted for swift currents (Ward and Kondratieff 1992, Vieira et al. 2006). Zapada, as noted above, is associated with cool, highly oxygenated streams. Micrasema is a genus of case-building trichopterans associated with clean, cool streams (Vieira et al. 2006). Paraleptophlebia is a mayfly genus associated with riffles in small streams but can also be found in slower habitats with some silt and elevated turbidity (Vieira et al. 2006). There is little information available on the general habitat associations of the case-building trichopteran, Gumaga; however, the genus has been well studied in smaller California Mediterranean climate streams and springs, similar to the northern and southern streams in this study, and it can become very abundant in such habitats (Resh et al. 1981, 1997, Jackson and Resh 1998).

Our second objective was to determine the associations of the benthic invertebrate assemblages with environmental variables, specifically habitat, water quality, and sediment quality. The BEST analysis indicated that the major habitat gradient (HAB 1) in stream size, gradient, and riffle habitat best accounted for the overall pattern in assemblage composition, with the secondary habitat gradient (HAB 2) and the primary water quality gradient significantly improving the overall model.

The importance of flow to stream invertebrate assemblages has been well established for Mediterranean-climate northern California streams (Gasith and Resh 1999, Bêche and Resh 2007, Power et al. 2008, Bêche et al. 2009). The presence of riffles between pools is important in maintaining habitat connectivity, which can have important effects on taxonomic composition of assemblages (Bonada et al. 2006). In our study, the higher flows in the mainstem Clear Creek clearly separated those sites from the other streams, and the dominance of riffles and higher water velocities separated the Clear Creek sites below the reservoir from those above the reservoir (Fig. 4). Similar groupings of sites are apparent in the NMS plots (Figs. 2, 3). The disruptive effects of dams on benthic invertebrate assemblages have been known for many years (Ward and Stanford 1983, Stanford and Ward 2001), and effects of flow regime alterations on benthic invertebrate assemblages have been documented in California streams (Rehn 2009).

The interesting feature in our results was that the lower Clear Creek sites had assemblages similar to the high-gradient, riffle-dominated smaller streams (Figs. 2, 3). The high flows below the dam resulted in high percentages of riffle habitat that were similar to percentages of riffle habitat in smaller, highergradient streams (Table 1) and favored the same genera of macroinvertebrates (NMS 1 in Figs. 2, 3). However, there was a second group of genera (e.g., Paraleptophlebia and Gumaga) that was more indicative of conditions in the smaller streams (Figs. 2, 3). Elevated summer flows associated with reservoir releases are a common feature of California rivers used for water supply (Brown and Bauer 2010), providing opportunities to determine whether the patterns we observed are generalizable or unique to Clear Creek.

The influence of water quality on macroinvertebrate assemblages appears to be associated both with general water quality and the influence of mining. The associations of dissolved metals from mining with benthic macroinvertebrate assemblages have been well explored in the western United States (Leland et al. 1989, Maret et al. 2003, Clements 2004, Cain et al. 2004). In highly contaminated areas, metals contamination can be a primary influence on assemblage composition. Detailed studies have established taxon-specific differences in responses to metal contamination (Cain et al. 2004, Buchwalter et al. 2008). The secondary influence of water quality in our study, as indicated by the BEST analysis, suggests that dissolved metals were not having a major influence on macroinvertebrate assemblages, with the exception of Willow Creek. Willow Creek was the only site considered by the State of California as impaired by metal 
contamination (California State Water Resources Control Board 2010) and the only site exceeding the CCC for any metal. Compared to the other sites, Willow Creek was definitely an outlier with respect to major ions and dissolved metals (Fig. 5). Willow Creek was also an outlier in the NMS plots (Figs. 2, 3). The dominant taxa $(>10 \%$ of abundance) in Willow Creek were simuliids (blackflies) and hydropsychid caddisflies in 2004 and baetid mayflies and hydropsychid caddisflies in 2005. These taxa are seemingly tolerant of metal contamination associated with mining in western U.S. streams (Clements et al. 2000, Cain et al. 2004, Pollard and Yuan 2006). In general, water quality seems to be reflecting the underlying geology, with the southern streams clearly different from the northern streams (Fig. 5). This separation was also evident in the NMS plots (Figs. 2, 3), although the separation was not perfect. Thus, water quality provides separation among the smaller southern and northern streams that was not evident based on habitat alone (Fig. 4).

Our third objective was to evaluate the use of an IBI to evaluate stream biological condition. The northern California IBI indicated that the streams in the study area are in fair to very good condition, except for Willow Creek (2004). The RW and TR samples gave similar mean IBI values and categorical results. This result is consistent with Rehn et al. (2007) who found that RW and TR samples are generally interchangeable when used to determine biological indicators for use in ambient biomonitoring programs. Similarly, Maret et al. (2001) found that a TR-type sample and a reach-wide multihabitat sample gave similar results when used to compute a multimetric invertebrate index. In our study, the reach-wide samples did capture a somewhat wider range of scores than the targeted-riffle samples (33-91 and 50-86, respectively), resulting in the wider range of condition categories (Fig. 7). Given that the 2 sample types give very similar results, we would suggest that the reach-wide method be used if a biomonitoring program is implemented in the area, for the simple reason that this method can be used in streams without clearly defined riffles. Whichever method is selected, the same method should be used at all sites to ensure maximum comparability of results. It is also worth noting that the IBI results support the idea that water quality is not a major negative influence on macroinvertebrate assemblages, except in Willow Creek.

If a biomonitoring program is implemented for the upper Clear Creek drainage, some caution will be necessary in interpreting results until the range of interannual variability in macroinvertebrate assemblages and IBI scores can be established. As noted earlier, the cycles of flood and drought common to Mediterranean climates can have large effects on macroinvertebrate assemblages (Gasith and Resh 1999, Bêche and Resh 2007, Bêche et al. 2009) and food webs (Feminella et al. 1989, Wooton et al. 1996, Power et al. 2008). This climate-driven variability can result in variability in the metrics used to calculate the IBI; however, the multimetric nature of the IBI tends to minimize the effects of such variability on annual patterns to some extent (Mazor et al. 2009). Presumably, monitoring through both a multiple-year drought and one or more flood years would be necessary to capture the full range of climatic influence on IBI scores.

Our final objective was to consider our results in the context of biodiversity of the Klamath-Siskyou Ecoregion, a globally significant area for biodiversity of terrestrial plant and animal communities (DellaSala et al. 1999). The area also has highly endemic fish and aquatic mollusk faunae, but primarily in the Klamath part of the ecoregion north of our study area, which is in the southern end of the Siskyou region. However, the aquatic communities of the Clear Creek watershed contribute to the unique character of the ecoregion even without the presence of endemic species. Brown and May (2007) observed that the vertebrate aquatic assemblages of the upper Clear Creek drainage represented a unique combination of Central Valley and North Coast faunae, which represented another manifestation of the unique geology, physiography, and ecology of the Klamath-Siskyou region. Similarly, the aquatic macroinvertebrates collected in our study are not unusual for California streams; however, the diversity of assemblages we observed is a direct manifestation of the range of geology, topography, and hydrology of the region. The generally good condition of the streams and the presence of intact macroinvertebrate assemblages may help explain the continued success of the native aquatic vertebrates in the upper Clear Creek drainage, in 
contrast to many other areas of California where degraded habitat quality has been associated with the success of invasive species (Brown and Moyle 2005, Marchetti et al. 2001, 2006). Although a large portion of the land in the area is in federal ownership, human activities will continue to affect the area, particularly as nearby urban areas (primarily Redding but also Red Bluff and Sacramento) continue to expand and the demand for recreation, resource extraction, agricultural production, and other amenities increases. Maintaining the aquatic habitats in good condition is important in itself but is also vital to maintaining biodiversity in this diverse and unique ecoregion.

\section{ACKNOWLEDGMENTS}

We thank the personnel of Whiskeytown National Recreation Area, especially Jennifer Gibson and Windy Bunn, for help in all phases of the study. We also thank everyone who reviewed early versions of the manuscript and provided many comments that substantially improved the final article.

\section{Literature Cited}

ALLAN, J.D. 2004. Landscapes and riverscapes: the influence of land use on stream ecosystems. Annual Reviews in Ecology, Evolution and Systematics 35: 257-284.

Bêche, L.A., P.G. Connors, V.H. Resh, and A.M. Merenlender. 2009. Resilience of fishes and invertebrates to prolonged drought in two California streams. Ecography 32:778-788.

BÊCHE, L.A., AND V.H. REsH. 2007. Biological traits of benthic macroinvertebrates in California mediterranean-climate streams: long-term annual variability and trait diversity patterns. Fundamental and Applied Limnology 169:1-23.

Bonada, N., M. Rieradevall, N. Prat, and V.H. Resh. 2006. Benthic macroinvertebrate assemblages and macrohabitat connectivity in Mediterranean-climate streams of northern California. Journal of the North American Benthological Society 25:32-43.

Brown, L.R., AND M.L. Bauer. 2010. Effects of hydrologic infrastructure on flow regimes of California's Central Valley rivers: implications for fish populations. River Research and Applications 26: $751-765$.

Brown, L.R., AND J.T. MaY. 2007. Aquatic vertebrate assemblages of the upper Clear Creek watershed, California. Western North American Naturalist 67: $439-451$.

Brown, L.R., AND P.B. MoyLE. 2005. Native fish communities of the Sacramento-San Joaquin watershed, California: a history of decline. Pages 75-98 in F. Rinne, R. Hughes, and R. Calamusso, editors, Fish communities of large rivers of the United States. American Fisheries Society, Bethesda, MD.

Buchwalter, D.B., D.J. Cain, C.A. Martin, L. Xie, S.N. LUOMA, AND T. GaRLand JR. 2008. Aquatic insect ecophysiological traits reveal phylogenetically based differences in dissolved cadmium susceptibility. Proceedings of the National Academy of Sciences 105: 8321-8326.

Bury, R.B., AND C.A. PEARL. 1999. Klamath-Siskiyou herpetofauna: biogeographic patterns and conservation strategies. Natural Areas Journal 19:341-350.

Cain, D.J., S.N. Luoma, and W.G. Wallace. 2004. Linking metal bioaccumulation of aquatic insects to their distributional patterns in a mining-impacted river. Environmental Toxicology and Chemistry 23: 1463-1473.

California State Water Resources Control Board. 2010. 2010 Integrated Report (Clean Water Act Section 303(d) List / 305(b) Report). California State Water Resources Control Board, Sacramento, CA. Available from: http://www.swrcb.ca.gov/water_issues/pro grams/tmdl/integrated2010.shtml

Clarke, K.R., and R.N. Gorley. 2006. Primer v6: user manual/tutorial. Primer-E, Plymouth, United Kingdom.

Clements, W.H. 2004. Small-scale experiments support causal relationships between metal contamination and macroinvertebrate community responses. Ecological Applications 14:954-967.

Clements, W.H., D.M. Carlisle, J.M. LazorchaK, and P.C. Johnson. 2000. Heavy metals structure benthic communities in Colorado mountain streams. Ecological Applications 10:626-638.

Dellasala, D.A., S.B. Reid, T.J. Frest, J.R. Strittholt, AND D.M. Olson. 1999. A global perspective on the biodiversity of the Klamath-Siskiyou ecoregion. Natural Areas Journal 19:300-319.

Feminella, J.W., M.E. Power, and V.H. Resh. 1989. Periphyton responses to invertebrate grazing and riparian canopy in three northern California coastal streams. Freshwater Biology 22:445-457.

Fishman, M.J., AND L.C. Friedman. 1989. Methods for determination of inorganic substances in water and fluvial sediments. U.S. Geological Survey Techniques of Water-Resources Investigations. Book 5, Chap. Al.

FitZPatrick, F.A., I.R. Waite, P.J. D'ArConte, M.R. Meador, M.A. Maupin, and M.E. Gurtz. 1998. Revised methods for characterizing stream habitat in the national water-quality assessment program. Water-Resources Investigations Report 98-4052. U.S. Geological Survey, Raleigh, NC. Available from: http://pubs.usgs.gov/wri/wri984052/pdf/wri98 4052.pdf

Garbarino, J.R. 1999. Methods of analysis by the U.S. Geological Survey National Water Quality Laboratory-determination of dissolved arsenic, boron, lithium, selenium, strontium, thallium, and vanadium using inductively coupled plasma-mass spectrometry. U.S. Geological Survey Open-File Report 99-093.

Garbarino, J.R., L.K. Kanagy, and M.E. Cree. 2006. Determination of elements in natural-water, biota, sediment and soil samples using collision/reaction cell inductively coupled plasma-mass spectrometry. U.S. Geological Survey Techniques and Methods, book 5 , sec. B, chap. 1 . 
Garbarino, J.R., and T.M. Struzeski. 1998. Methods of analysis by the U.S. Geological Survey National Water Quality Laboratory-determination of elements in whole-water digests using inductively coupled plasma-optical emission spectrometry and inductively coupled plasma-mass spectrometry. U.S. Geological Survey Open-File Report 98-165.

Gasith, A., AND V.H. Resh. 1999. Streams in Mediterranean climate regions: abiotic influences and biotic responses to predictable seasonal events. Annual Reviews in Ecology and Systematics 30:51-81.

Gaufin, A.R. 1973. Use of aquatic invertebrates in the assessment of water quality. Pages 96-116 in Biological methods for the assessment of water quality, ASTM STP 528. American Society for Testing and Materials. Available from: http://www.astm.org/DIG ITAL LIBRARY/STP/PAGES/STP34719S.htm

Harrington, J.M. 1999. California state bioassess ment procedure. California Department of Fish and Game, Water Pollution Control Laboratory, Rancho Cordova, CA

HilsenhofF, W.L. 1988. Rapid field assessment of organic pollution with a family-level biotic index. Journal of the North American Benthological Society 7:65-68.

Hoffman, G.L., M.J. Fishman, and J.R. Garbarino. 1996. Methods of analysis by the U.S. Geological Survey National Water Quality Laboratory-in-bottle acid digestion of whole-water samples. U.S. Geological Survey Open-File Report 96-225.

Hynes, H.B.N. 1970. The ecology of running waters. University of Toronto Press, Toronto, Ontario, Canada.

JACKSON, J.K., AND V.C. RESH. 1998. Morphologically cryptic species confound ecological studies of the caddisfly genus Gumaga (Trichoptera: Sericostomatidae) in northern California. Aquatic Insects 20 69-84.

Jennings, M.R., And M.P. Hayes. 1994. Amphibian and reptile species of special concern in California. California Department of Fish and Game, Inland Fisheries Division, Sacramento, CA. Available from: http://www.dfg.ca.gov/habcon/info/herp_ssc.pdf

KARR, J.R., AND E.W. CHU. 1999. Restoring life in running waters: better biological monitoring. Island Press, Washington, DC.

Kerans, B.L., And J.R. Karr. 1994. A Benthic Index of Biotic Integrity (B-IBI) for rivers of the Tennessee Valley. Ecological Applications 4:768-785.

KNAPP, R.A. 2005. Effects of nonnative fish and habitat characteristics on lentic herpetofauna in Yosemite National Park, USA. Biological Conservation 121: 265-279.

Knapp, R.A., And K.R. Matthews. 2000. Non-native fish introductions and the decline of mountain yellowlegged frogs from within protected areas. Conservation Biology 14:428-438.

Kruskal, J.B. 1964a. Multidimensional scaling by optimizing goodness of fit to a nonmetric hypothesis. Psychometrika 29:1-27.

1964b. Nonmetric multidimensional scaling: a numerical method. Psychometrika 29:115-129.

Legendre, P., AND L. LEgEndRE. 1998. Numerical ecology. 2nd English edition. Elsevier Scientific Publishing Company, Amsterdam.

Leland, H.V., S.V. Fend, T.L. Dudley, and J.L. Carter. 1989. Effects of copper on species composition of benthic insects in a Sierra Nevada, California, stream. Freshwater Biology 21:163-179.
MacDonald, D.D., C.G. Ingersoll, and T.A. Berger. 2000. Development and evaluation of consensusbased sediment quality guidelines for freshwater ecosystems. Archives of Environmental Contamination and Toxicology 39(1):20-31.

Marchetti, M.P., T. Light, J. Feliciano, T. Armstrong, Z. Hogan, J. Viers, and P.B. MoYle. 2001. Homogenization of California's fish fauna through abiotic change. Pages 259-278 in J. Lockwood and M. McKinney, editors, Biotic homogenization. Kluwer Academic/Plenum Publishers.

Marchetti, M.P., J.L. LockWOOD, AND T. Light. 2006. Effects of urbanization on California's fish diversity: differentiation, homogenization and the influence of spatial scale. Biological Conservation 127:310-318.

Maret, T.R., D.J. Cain, D.E. MacCoy, and T.M. Short. 2003. Response of benthic invertebrate assemblages to metal exposure and bioaccumulation associated with hard-rock mining in northwestern streams, USA. Journal of the North American Benthological Society 22:598-620.

Maret, T.R., D.E. MacCoy, K.D. Skinner, S.E. Moore, AND I. O'DELL. 2001. Evaluation of macroinvertebrate assemblages in Idaho rivers using multimetric and multivariate techniques, 1996-98. U.S. Geological Survey Water-Resources Investigation Report 01-4145. Available from: http://id.water.usgs.gov/ PDF/wri014145/.

Mather, P.M. 1976. Computational methods of multivariate analysis in physical geography. J. Wiley \& Sons, London.

Matthews, K.R., K.L. Pope, H.K. Preisler, and R.A. KNAPP. 2001. Effects of non-native trout on Pacific treefrogs (Hyla regilla) in the Sierra Nevada. Copeia 2001:1130-1137.

Mazor, R.D., A.H. Purcell, AND V.H. Resh. 2009. Longterm variability in bioassessments: a twenty-year study from two northern California streams. Environmental Management 43:1269-1286.

McCune, B., AND J.B. Grace. 2002. Analysis of ecological communities. MjM Software Design, Gleneden Beach, OR.

Moore, J.M. 2002. Trace metals in sediments from mineimpacted rivers: Clear Creek, California. Final Contract Report, 02WRAG001. University of Montana, Missoula, MT.

Moore, J.M., AND D. Hughes, 2003. Trace metals in sediments of a mine impated river basin: Clear Creek California Project. Department of Geology, University of Montana, Missoula, MT.

MoyLe, P.B. 2002. Inland fishes of California. Revised and expanded. University of California Press, Berkeley, CA.

Nakano, S., And M. Murakami. 2001. Reciprocal subsidies: dynamic interdependence between terrestrial and aquatic food webs. Proceedings of the National Academy of Sciences 98:166-170.

Nakano, S., H. Mrasaka, and N. Kuhara. 1999. Terrestrial-aquatic linkages: riparian arthropod inputs alter trophic cascades in a stream food web. Ecology 80: 2435-2441.

Ode, P.R., A.C. Rehn, And J.T. May. 2005. A quantitative tool for assessing the integrity of southern coastal California streams. Environmental Management 35: 493-504.

Peck, D.V., A.T. Herlihy, B.H. Hill, R.M. Hughes, P.R. Kaufmann, D.J. Klemm, J.M. LazorchaK, F.H. McCormick, S.A. Peterson, P.L. Ringold, et AL 
2006. Environmental Monitoring and Assessment Program-Surface Waters Western Pilot Study: field operations manual for wadeable streams. EPA/620/ R-06/003. U.S. Environmental Protection Agency, Office of Research and Development, Washington, DC. Available from: http://www.epa.gov/wed/pages/ publications/authored/EPA620R-06003EMAP SWFieldOperationsManualPeck.pdf

Pollard, A.I., AND L. Yuan. 2006. Community response patterns: evaluating benthic invertebrate composition in metal-polluted streams. Ecological Applications 16:645-655.

Power, M.E., M.S. Parker, and W.E. Dietrich. 2008. Seasonal reassembly of a river food web: floods droughts, and impacts of fish. Ecological Monographs 78:263-282.

Rehn, A.C. 2009. Benthic macroinvertebrates as indicators of biological condition below hydropower dams on west slope Sierra Nevada streams, California, USA. River Research and Applications 25:208-228.

Rehn, A.C., P.R. Ode, AND C.P. HaWkins. 2007. Comparisons of targeted-riffle and reach-wide benthic macroinvertebrate samples: implications for data sharing in stream-condition assessments. Journal of the North American Benthological Society 26:332-348.

Rehn, A.C., P.R. Ode, AND J.T. MaY. 2005. Development of a benthic index of biotic integrity (B-IBI) for wadeable streams in Northern Coastal California and its application to regional 305(b) assessment. Final Technical Report, State Water Resources Control Board, Sacramento, CA. Available from: http:// www.swrcb.ca.gov/water_issues/programs/swamp/do cs/reports/final_north_calif_ibi.pdf

REsh, V.H., T.S. FLYNN, G.A. LAMBERTI, E.P. MCELraVY, K.L. SorG, AND J.R. WOOD. 1981. Responses of the sericostomatid caddisfly Gumaga nigricola (McL.) to environmental disruption. Pages $311-318$ in G.P. Moretti, editor, Proceedings of the Third International Symposium on Trichoptera. Junk, The Hague.

Resh, V.H., J.R. Wood, E.A. Bergey, J.W. Feminella, J.K. JaCKSON, AND E.P. MCELRAVY. 1997. Biology of Gumaga nigricula (McL.) in a northern California stream. Pages 401-410 in R.W. Holenthal and O.S Flint Jr., editors, Proceedings of the 8th International Symposium on Trichoptera. Ohio Biological Survey, Columbus $\mathrm{OH}$.

Reynoldson, T.B., and J.L. Metcalfe-Smith. 1992. An overview of the assessment of aquatic ecosystem health using benthic invertebrates. Journal of Aquatic Ecosystem Stress and Recovery 1:295-308.

Shelton, L.R. 1994. Field guide for collecting and processing stream-water samples for the National Water-Quality Assessment Program. U.S. Geological Survey Open-File Report 94-455. Available from: http://water.usgs.gov/nawqa/pnsp/pubs/ofr94455/ sw-t.html

Shelton, L.R., AND P.D. Capel. 1994. Guidelines for collecting and processing samples of stream bed sediment for analysis of trace elements and organic contaminants for the National Water-Quality Assessment Program. U.S. Geological Survey Open-File Report 94-458. Available from: http://water.usgs.gov/nawqa/ pnsp/pubs/ofr94-458/.

STANFORD, J.A., AND J.V. WARD. 2001. Revisiting the serial discontinuity concept. Regulated Rivers: Research and Management 17:303-310.

Thornberry-Ehrlich, T. 2007. Whiskeytown National Recreation Area geologic resource evaluation report. Natural Resource Report NPS/NRPC/GRD/NRR2007/008, National Park Service, Denver, CO. Available from: http://www.nature.nps.gov/geology/inven tory/publications/reports/whis_gre_rpt_view.pdf

[USGS] United States Geological Survey. 2012. Water-resources data for the United States, Water Year 2011: U.S. Geological Survey Water-Data Report WDR-US-2011, site 11372000. Available from: http://wdr.water.usgs.gov/wy2011/pdfs/113720 00.2011.pdf

Vannote, R.L., G.W. Minshall, K.W. Cummins, J.R. SEDELl, AND C.E. Cushing. 1980. The river continuum concept. Canadian Journal of Fisheries and Aquatic Sciences 37:130-137.

Vieira, N.K.M., N.L. Poff, D.M.Carlisle, S.R. Moulton II, M.L. Koski, and B.C. KondratiefF. 2006. A database of lotic invertebrate traits for North America. U.S. Geological Survey Data Series 187. Available from: http://pubs.water.usgs.gov/ds187

Ward, J.V., AND B.C. KondratiefF. 1992. An illustrated guide to the mountain stream insects of Colorado. University Press of Colorado, Niwot, CO.

WARD, J.V., AND J.A. STANFORD. 1983. Serial discontinuity concept of lotic ecosystems. Pages 29-42 in T.D. Fontaine and S.M. Bartell, editors, Dynamics of lotic systems. Ann Arbor Science, Ann Arbor, MI.

Welsh, H.W., JR., K.L. Pope, AND D. Boiano. 2006. Subalpine amphibian distributions related to species palatability to non-native salmonids in the Klamath Mountains of northern California. Diversity and Distributions 12:298-309. Available from: http:// www.fs.fed.us/psw/publications/welsh/captured/psw 2006 welsh009.pdf

Wooton, J.T., M.S. Parker, and M.E. Power. 1996. Effects of disturbance on river food webs. Science 5281:1558-1561. Available from: http://www.sci encemag.org/content/273/5281/1558

Received 5 January 2012 Accepted 28 July 2012 